\title{
A Lagrangian analysis of the impact of transport and transformation on the ozone stratification observed in the free troposphere during the ESCOMPTE campaign
}

\author{
A. Colette ${ }^{1}$, G. Ancellet ${ }^{1}$, L. Menut ${ }^{2}$, and S. R. Arnold ${ }^{3}$ \\ ${ }^{1}$ Service d'Aéronomie/Institut Pierre-Simon Laplace, Centre National de la Recherche Scientifique, Université Pierre et \\ Marie Curie, 4, place Jussieu, P.O. Box 102, 75252 Paris Cedex 05, France \\ ${ }^{2}$ Laboratoire de Météorologie Dynamique/Institut Pierre-Simon Laplace, Centre National de la Recherche Scientifique, Ecole \\ Polytechnique, 91128 Palaiseau Cedex, France \\ ${ }^{3}$ Institute for Atmospheric Science, School of Earth and Environment, University of Leeds, Leeds, LS2 9JT, UK
}

Received: 11 November 2005 - Published in Atmos. Chem. Phys. Discuss.: 21 March 2006

Revised: 28 June 2006 - Accepted: 3 August 2006 - Published: 25 August 2006

\begin{abstract}
The ozone variability observed by tropospheric ozone lidars during the ESCOMPTE campaign is analyzed by means of a hybrid-Lagrangian modeling study. Transport processes responsible for the formation of ozone-rich layers are identified using a semi-Lagrangian analysis of mesoscale simulations to identify the planetary boundary layer (PBL) footprint in the free troposphere. High ozone concentrations are related to polluted air masses exported from the Iberian PBL. The chemical composition of air masses coming from the PBL and transported in the free troposphere is evaluated using a Lagrangian chemistry model. The initial concentrations are provided by a model of chemistry and transport. Different scenarios are tested for the initial conditions and for the impact of mixing with background air in order to perform a quantitative comparison with the lidar observations. For this meteorological situation, the characteristic mixing time is of the order of 2 to 6 days depending on the initial conditions. Ozone is produced in the free troposphere within most air masses exported from the Iberian PBL at an average rate of $0.2 \mathrm{ppbvh}^{-1}$, with a maximum ozone production of $0.4 \mathrm{ppbv} \mathrm{h}^{-1}$. Transport processes from the PBL are responsible for an increase of $13.3 \mathrm{ppbv}$ of ozone concentrations in the free troposphere compared to background levels; about $45 \%$ of this increase is attributed to in situ production during the transport rather than direct export of ozone.
\end{abstract}

Correspondence to: A. Colette

(augustin.colette@aero.jussieu.fr)

\section{Introduction}

Transport and transformation of photochemically reactive species in the troposphere are topics of sustained attention. Ozone is one of the main oxidants in the atmosphere; it is either produced in the stratosphere, the planetary boundary layer (PBL) or the free troposphere (FT). In the PBL, ozone precursors include biogenic and anthropogenic emissions (from both transports and industrial activities). Once in the troposphere, ozone can be transported over long distances enhancing local pollution in remote places (Zhang and Trivikrama Rao, 1999) or perturbing fragile equilibrium in pristine areas (e.g. when transported to the poles, Eckhardt et al., 2003). In addition, increased background ozone concentrations in the troposphere play an important role in global climate change because of its radiative properties (Bernsten et al., 1997).

In this paper, we focus on transport processes from the PBL and their impact on free tropospheric ozone variability. Cotton et al. (1995) suggest that the PBL is vented toward the FT 90 times per year on a global scale. This coupling occurs through a wide spectrum of transport mechanisms: local circulations - either orographic (Henne et al., 2004) or sea breezes (Bastin and Drobinski, 2006), convective systems (Hauf et al., 1995) or frontal systems (Cooper et al., 2002). If such transport processes occur above polluted areas, they export ozone or its precursors to the FT.

The European ESCOMPTE program (Expérience sur Site pour Contraindre les Modèles de Pollution Atmosphérique et de Transport d'Emissions, Cros et al., 2004) was designed to gather measurements in order to better assess atmospheric

Published by Copernicus GmbH on behalf of the European Geosciences Union. 
chemistry transport models (CTM). Many publications related to the ESCOMPTE campaign are included in Cros and Durand (2005). During this campaign, several tropospheric ozone profilers were operated, so that the ozone stratification above the PBL and its temporal evolution are well documented (Ancellet and Ravetta, 2005).

The goal of the present study is first to identify the transport mechanisms responsible for the observed ozone variability in the FT, and second to assess the photochemical transformation occurring during the transport. Three models are coupled to achieve a hybrid-Lagrangian reconstruction of the observed ozone variability. A mesoscale non-hydrostatic model is used to compute high-resolution backtrajectories in order to identify air masses coming from the polluted PBL. A CTM designed for PBL simulations allows the evaluation of the chemical composition of selected air masses at the time and place of export from the PBL. Then, photochemical transformation during the transport is computed using a Lagrangian chemistry model. This approach leads to a reconstruction of the ozone variability that matches observations and allows the discussion of the impact of mixing with background air as well as the quantification of ozone production rates for different transport pathways. The advantages of such a Lagrangian approach compared to Eulerian simulations are twofold. First, at similar computational cost, scales resolved with a Lagrangian model are smaller (Norton, 1994), which is of crucial importance considering the large ozone variability observed during ESCOMPTE. Second, by tracking air masses, it allows a better understanding of their temporal evolution during the transport.

The field campaign, ozone lidar measurements and the general synoptic context are presented in Sect. 2. Section 3 addresses the results of the hybrid-Lagrangian analysis of the observed tropospheric ozone variability. A mesoscale modeling study leads to the identification of transport processes discussed in Sect. 3.1. The influence of photochemical transformation is investigated in Sects. 3.2 and 3.3. First, we describe a purely advective reconstruction of the ozone variability with a reverse domain filling method. Second, a Lagrangian chemistry model is used to simulate the transformation occurring during the transport in the free troposphere; so that a quantitative comparison with lidar observations can eventually be conducted.

\section{The ESCOMPTE campaign}

\subsection{General description}

The ESCOMPTE campaign (Cros et al., 2004) took place in June and July 2001 in the Aix-Marseille area (South-Eastern France). The region is densely inhabited; iron, steel, petrochemistry factories and oil refineries are located around the Berre pond. The area is thus highly exposed to anthropogenic emissions of pollutants both from transports and industrial activities. The local vegetation is also an important source of volatile organic compounds.

In the ESCOMPTE region, a wide range of dynamic forcing plays a role in trace gases circulation. Within the PBL, valley breezes develop in the Alpilles and Lubéron massifs and in the Durance and Rhône valleys. Strong sea breezes that can penetrate as far as $100 \mathrm{~km}$ inland are frequently observed (Bastin et al., 2005; Puygrenier et al., 2005). At night, land breezes can store polluted air masses above the maritime boundary layer and thus build reservoirs of aged polluted air that may return onshore on the following day (Gangoiti et al., 2001; Ancellet and Ravetta, 2005). Above the PBL, local circulations have a limited impact and synoptic and mesoscale processes predominate. When a trough is located over the Balkan countries, the Alps and Massif Central channel a strong northerly flow (the Mistral) that shall carry anthropogenic trace gases from the Lyons and Paris agglomerations (Corsmeier et al., 2005). In the following, we will discuss in details how intra-European transport can import polluted air masses to the ESCOMPTE domain. Last, this area is exposed to the long-range transport of polluted air masses; Lelieveld et al. (2002) suggest that air masses transported through the Westerlies above the Northern Atlantic Ocean during summer often veer to South-Eastern France when reaching the European continent.

During the campaign, measurements included an enhanced network of ground based stations, balloon soundings, constant volume balloon flights, sodars, radars, wind and ozone lidars and 6 instrumented aircrafts. In the present paper, we will primarily use measurements performed by the Service d'Aéronomie (CNRS, France) with the tropospheric lidar ALTO (Ancellet and Ravetta, 1998).

\subsection{Selection of the time frame}

Four intensive observation periods (IOP) were conducted during the ESCOMPTE campaign. We performed a preliminary analysis to define the most interesting case studies in the framework of the coupling between the PBL and the FT. IOP2 (between 21 and 26 June) was recognized as an appropriate period because of its long duration, the variability of meteorological conditions monitored and the quality of the dataset available. A first trajectory analysis was performed using large-scale wind fields for the whole IOP2 to target the time frame when mesoscale transport influenced the tropospheric ozone variability in the ESCOMPTE area. For this purpose, we used the Lagrangian particle dispersion model FLEXPART 5.1 (Stohl et al., 1998). The model was driven by 6-hourly ECMWF operational analyses (T511L60) interleaved with forecasts every $3 \mathrm{~h}$ (ECMWF, 1995). The selected domain extended from $100 \mathrm{~W}$ to $40 \mathrm{E}$ of longitude and $20 \mathrm{~N}$ to $80 \mathrm{~N}$ of latitude. In addition to advective transport at the scale of the global reanalyses, the FLEXPART model accounts for subgrid-scale orographic and convective venting (Stohl et al., 2005), and its efficency at discriminating 
air masses coming from the PBL or from the tropopause region has been demonstrated in the past, e.g. by Stohl and Trickl (1999).

Ozone measurements performed on 21 and 22 June are presented in Ancellet and Ravetta (2005). The FLEXPART analysis shows that positive and negative ozone anomalies observed these days are associated to synoptic transport processes active above the Northern Atlantic Ocean.

According to the FLEXPART simulations, the highest proportion of free tropospheric air observed above the ESCOMPTE area coming from the European PBL (and thus possibly influenced by continental emissions) is found between 23 and 26 June. During this period, 33\% of the free troposphere below $5 \mathrm{~km}$ a.s.l. correspond to air masses recently extracted from the PBL, mostly above the Iberian Peninsula. Consequently, the 23 to 26 June period is well suited for an analysis of the impact of mesoscale coupling between the PBL and the FT on the ozone variability.

According to the FLEXPART model, the selected ozonerich air masses were free of any stratospheric signature. The hypothesis of a stratospheric origin is further discarded by considering aerosol backscatter measurements of the ALTO lidar presented in Ancellet and Ravetta (2005) that is clearly above typical values expected for stratospheric air masses. In addition, carbon monoxide measurements performed on board the Dornier aircraft (Saïd et al., 2005) indicate concentrations of about $150 \mathrm{ppbv}$ in the vicinity of the selected tropospheric layers on 24th June. This value is in the range expected for aged polluted air masses. On the contrary, in the PBL, CO concentrations exceed 200 ppbv for local pollution plumes and is of the order of 100 ppbv for clean air masses.

\subsection{Synoptic situation}

On 23 June a Mistral regime ends. During the following days, the axis of a strong ridge extending from Morocco to Norway moves slowly eastward over France and is associated with weak northwesterly to westerly winds in the free troposphere (see the meteorological analyses of the Deutscher Wetterdienst for 24 June at $500 \mathrm{hPa}$ on Fig. 1a). In the PBL, sea breezes develop daily. On 26 June, the wind regime turns southwesterly as the ridge moves eastward and a surface low pressure system develops South of Ireland. Consequently, this day is discarded from the following analysis.

At the surface, the analyses (e.g. Fig. 1b) show that a thermal low develops daily above Spain between 20 and 25 June. Millán et al. (1997) explain in details how such a situation favors the export of PBL air to the lower FT; orographic circulations and sea breezes playing an important role inland and along the coast, respectively. These two types of local circulations can also be observed in conjunction along mountainous coastlines. Millán et al. (1997) also mention the importance of the convective activity. METEOSAT infrared images suggest that shallow convection occurred between 21 and 25 June above Spain. However, it did not orga- nize in large Mesoscale Convective Systems (MCS); one of the strongest events is shown on Fig. 1c.

To sum up, the thermal low above Spain exports PBL air to the FT where it is advected to the ESCOMPTE domain by the weak westerly flow. The paths followed by air masses arriving above the ALTO measurement site below $5 \mathrm{~km}$ between 23 and 25 June are presented on Fig. 1d. Exclusively air parcels coming from the PBL are displayed; their trajectories illustrate well the synoptic situation summarized above.

\subsection{Ozone profiling}

The most complete coverage of free tropospheric ozone was performed by ground-based lidars. Two instruments were operated during the campaign. The Service d'Aéronomie (CNRS, France) operated the ALTO lidar at Aix-les-Milles $(5.48 \mathrm{E}, 43.58 \mathrm{~N}, 110 \mathrm{~m}$ a.s.l.). This instrument is based on the DIAL technique (DIfferential Absorption Lidar) using two wavelength pairs: $266-289 \mathrm{~nm}$ and $289-316 \mathrm{~nm}$. The first pair is very well suited for measurements at short distances (below $1.5 \mathrm{~km}$ ) although no reliable measurement can be performed below $0.5 \mathrm{~km}$. The second pair allows measurements up to $4-5 \mathrm{~km}$. The $316 \mathrm{~nm}$ signal is used for retrieving the aerosol backscattering ratio. Ozone is biased when estimated by the DIAL technique in the presence of high aerosol load. Consequently an additional correction is performed using the backscatter estimate at $316 \mathrm{~nm}$. When aerosols concentration is too high, uncertainty is so important that ozone measurements are discarded. Details on the instrument are given in Ancellet and Ravetta (1998). Aerosol measurements, ozone correction and validation of the measurements performed during ESCOMPTE can be found in Ancellet and Ravetta (2005). During the campaign, the spatial and temporal variability of tropospheric ozone was also documented by airborne and balloon borne instruments. A comparative analysis of in situ and remote sensing ozone measurements is described in Ancellet and Ravetta (2005) who show how to relate spatial variability revealed by the aircrafts with the temporal variability of the ground-based lidar.

The ALTO record is sparse, that is why lidar measurements by the Ecole Polytechnique Fédérale de Lausanne (EPFL, Switzerland) are also presented here (Simeonov et al., 2004). The instrument was based at Saint-Chamas ( $35 \mathrm{~km}$ west of Aix-les-Milles, 5.04 E, $43.32 \mathrm{~N}, 210 \mathrm{~m}$ a.s.1.). The EPFL record presents a good temporal continuity. The instrumental setup is very similar to the ALTO lidar however no correction of ozone in the presence of aerosols is performed. For both instruments, ozone measured above $4000 \mathrm{~m}$ a.g.l. is discarded because of the low signal to noise ratio.

Ozone records are presented on Figs. 2a and b. At first order, even if the instruments are not co-localized, these two datasets present some similar patterns. For both records, below $1500 \mathrm{~m}$ a.s.l. important local pollution plumes are 
(a)

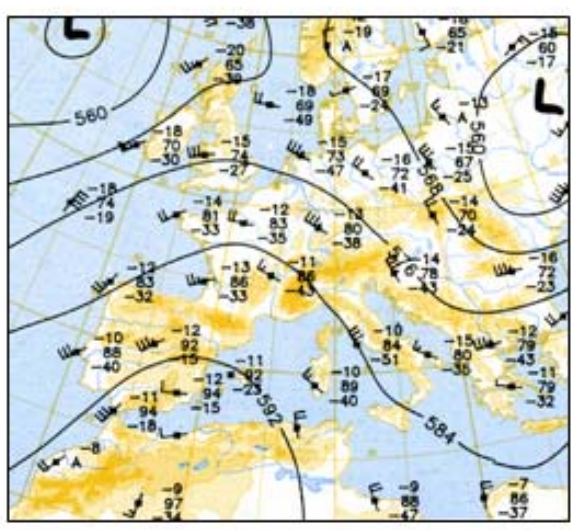

(c)

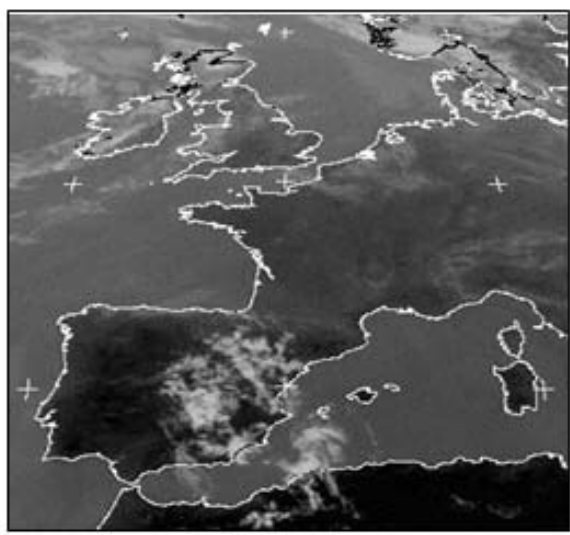

(b)

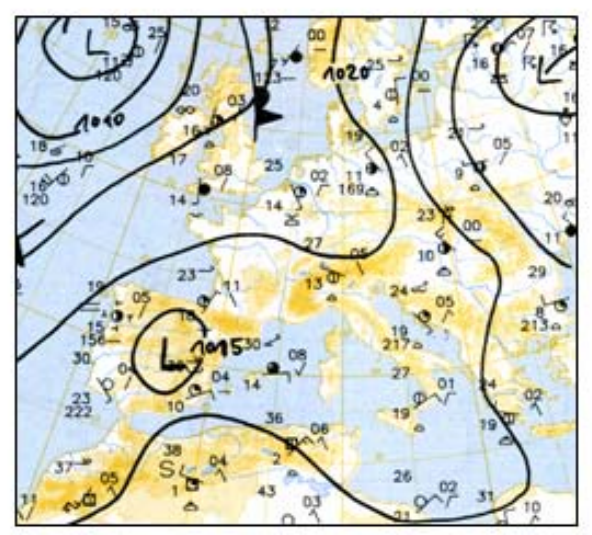

(d)

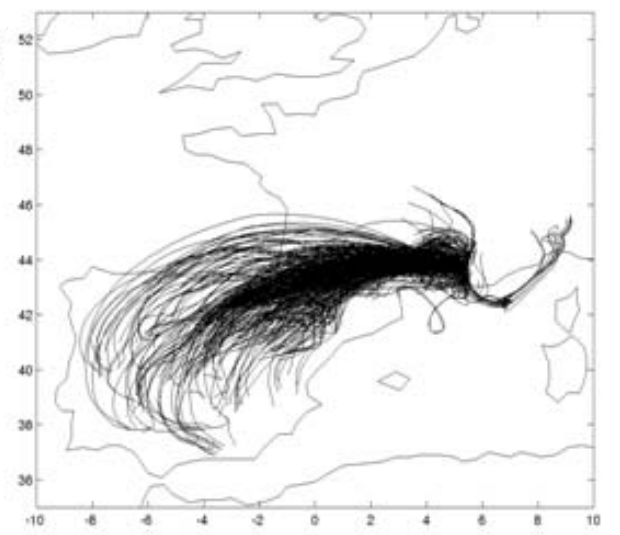

Fig. 1. Meteorological analyses of the Deutscher Wetterdienst for 24 June 2001 12:00 UT, geopotential at 500 hPa (a), and sea level pressure (b). METEOSAT infrared image for 24 June 12:00 UT (c). Mesoscale backtrajectories from the ALTO measurement site associated to PBL-FT coupling (d).

observed on 24 and 25 June. The synoptic situation is anticyclonic on these two days, which favors the development of sea breezes that can transport ozone produced in the lee of urban or industrial areas to the measurement sites. Regarding free tropospheric ozone variability, the most striking pattern is a large enhanced ozone structure observed between the afternoon of 23 June and the morning of 25 June centered at $2500 \mathrm{~m}$ a.s.l. Other interesting patterns include the low ozone concentrations measured in the morning of 23 June and an ozone depleted layer centered at $1500 \mathrm{~m}$ a.s.l. on 24 June.

More quantitatively, we found a $+10 \mathrm{ppbv}$ difference on average between EPFL and ALTO data for the 23 to 25 June period. To our understanding, the lack of aerosol correction in the EPFL algorithm should explain this offset. Consequently, EPFL data will be used for the qualitative comparison with modeled ozone variability, while ALTO measurements are preferred for the quantitative comparison of ozone concentrations (note that for a more appropriate reading of Fig. 2, we chose to account for this offset in the corresponding color scales).

\section{Modeling analyses}

The modeling analysis includes three steps: the identification of transport pathways with a 3-D mesoscale model $(\mathrm{MesoNH})$; the estimation of trace gases concentrations in the PBL when the air mass is exported to the FT using a CTM (CHIMERE); the analysis of the photochemical transformation during the transport using a Lagrangian chemistry model (CiTTyCAT).

\subsection{Transport pathways}

\subsubsection{Description of the MesoNH model}

MesoNH is a non-hydrostatic mesoscale model developed jointly at Laboratoire d'Aérologie (CNRS, France) and at the French Centre National de Recherche Météorologiques (Météo-France). Complete description of the model is given in Lafore et al. (1998); the version used here is 4.5.1. The domain is centered on Southern France with $72 \times 7230 \mathrm{~km}-$ wide grid cells. The vertical grid is terrain following with 48 levels ranging from $60 \mathrm{~m}$ to $19 \mathrm{~km}$ a.s.l., including 10 levels below $1 \mathrm{~km}$. The simulation is initialized and relaxed at the 
boundaries toward T511L60 ECMWF operational analyses (ECMWF, 1995). 7 simulations lasting $30 \mathrm{~h}$ each with $6 \mathrm{~h}$ of spin up were performed between 19 and 25 June 2001.

In these simulations semi-Lagrangian tracking of air parcels is activated (Gheusi and Stein, 2002). This method consists basically in modeling an additional variable in the Eulerian simulation: the 3-D field of the initial coordinates of the grid cells at the initialization of the run. Consequently, at each timestep, the initial position of every grid cell is known throughout the domain. In addition to advection, these air parcels undergo sub-grid scale processes such as turbulent mixing. In this study, the semi-Lagrangian analysis is used to compute backtrajectories that are more reliable for documenting mesoscale processes than classical Lagrangian trajectories, where wind fields are interpolated in the advection process.

\subsubsection{Mesoscale trajectories}

We mentioned in Sect. 2.2 that, according to the FLEXPART model, most air masses arriving above the ALTO measurement site are coming from the Iberian PBL. However this trajectory analysis can be significantly improved using the mesoscale simulation. Mesoscale backtrajectories were computed every hour between 23 and 25 June. Their ending points correspond to the ALTO measurement site every $250 \mathrm{~m}$ between the surface and $5000 \mathrm{~m}$ a.s.l. Trajectories are run for 3 days back in time. Indeed, considering the extension of the domain and free tropospheric wind velocities, the parcels leave the domain within 3 days if they remain in the FT. Turbulent kinetic energy (TKE) is interpolated from the mesoscale simulation along the trajectories to diagnose if air masses are coming from the PBL. If the TKE exceeds $0.2 \mathrm{~m}^{2} \mathrm{~s}^{-2}$ (Gheusi et al., 2004) for more than 3 contiguous hours of time, the air mass is considered as being inside the PBL. However, an additional test is required to discard TKE generated by clear air turbulence, i.e. when high TKE levels are modeled above $3000 \mathrm{~m}$ in the vicinity of mountain ranges in relation with lee waves breaking. At the altitudes considered (below $5000 \mathrm{~m}$ a.s.l.), turbulence related to shearing in the jet streak does not occur. With this TKE criterion we found that $48 \%$ of the trajectories are coming from the PBL among a total of about 1350 trajectories.

The results of the trajectory analysis are synthesized on Fig. 3. If during the $72 \mathrm{~h}$ before arriving in the ESCOMPTE area, the trajectory has been in the PBL, a square is plotted on the top panel at the time and altitude of arrival of the trajectory. On the second panel, the square is plotted at the location of export from the PBL. The color of the squares correspond to the time the air parcels spent in the FT. When this time is shorter than $2 \mathrm{~h}$, we can conclude that the corresponding air mass is influenced by the local PBL. Every afternoon, such air masses are detected above the observation site, in relation with the diurnal cycle of the PBL. This evolution of the local $\mathrm{PBL}$ is correlated with the enhanced ozone concentrations
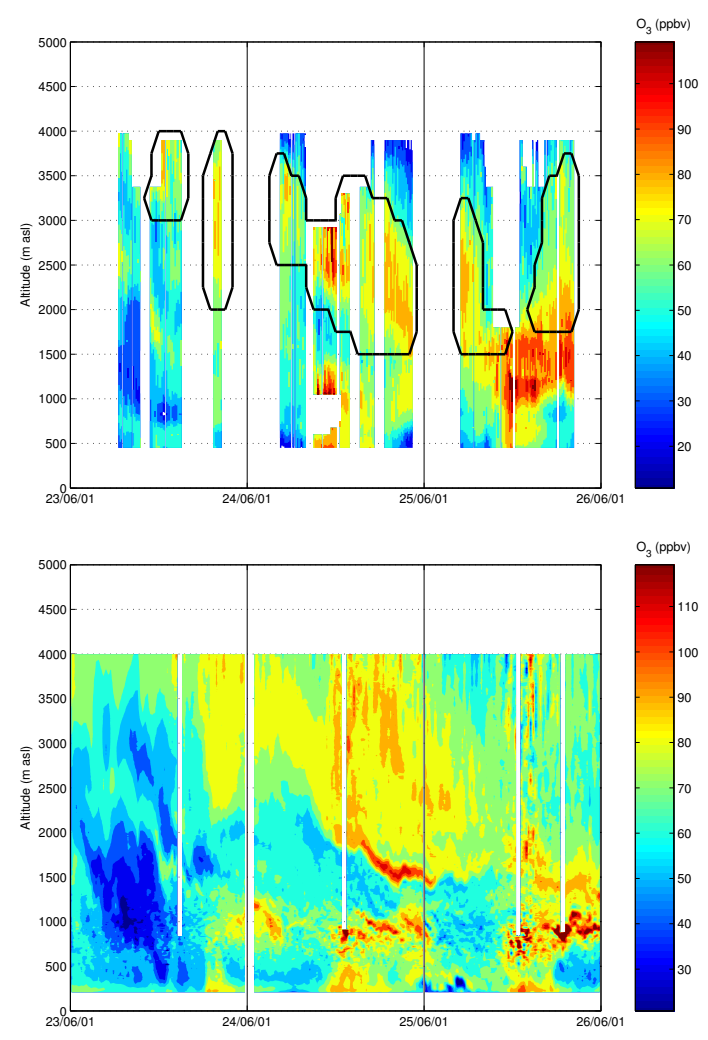

Fig. 2. Tropospheric ozone profiles measured by the ALTO (a) and EPFL (b) lidars between 23 and 25 June in the ESCOMPTE area. Color scales differ to account for the $10 \mathrm{ppbv}$ offset between the instruments.

measured by the lidar at mid-day in the $1000-1500 \mathrm{~m}$ altitude range which suggest a connection with local pollution plumes. Among the trajectories arriving above $750 \mathrm{~m}$ a.s.l., $17 \%$ were extracted from the PBL in the ESCOMPTE region and $31 \%$ are associated to an export from the Iberian PBL one to two days before the end of the trajectory.

The main free tropospheric ozone-rich layer centered around $2500 \mathrm{~m}$ on 24 June (Fig. 2) matches well with the footprint of air masses exported from the distant PBL on Fig. 3a. The trajectory analysis shows that this layer is constituted of air masses coming from widespread locations above Spain; but the relative homogeneity of a single tracer such as ozone in these air masses is not necessarily contradictory with their very variable geographical origins. Compared to this event, observed ozone concentrations are slightly lower after 14:00 UT on 25 June in the altitude range $2500-3000 \mathrm{~m}$. This feature can be related to the heterogeneity of the origins of the air masses according to the mesoscale model. Using global GCM simulations, Dufour et al. (2005), attributed the decrease of ozone concentrations observed on this day to vertical mixing with a tropical air mass in the upper layers. This hypothesis on the vertical 

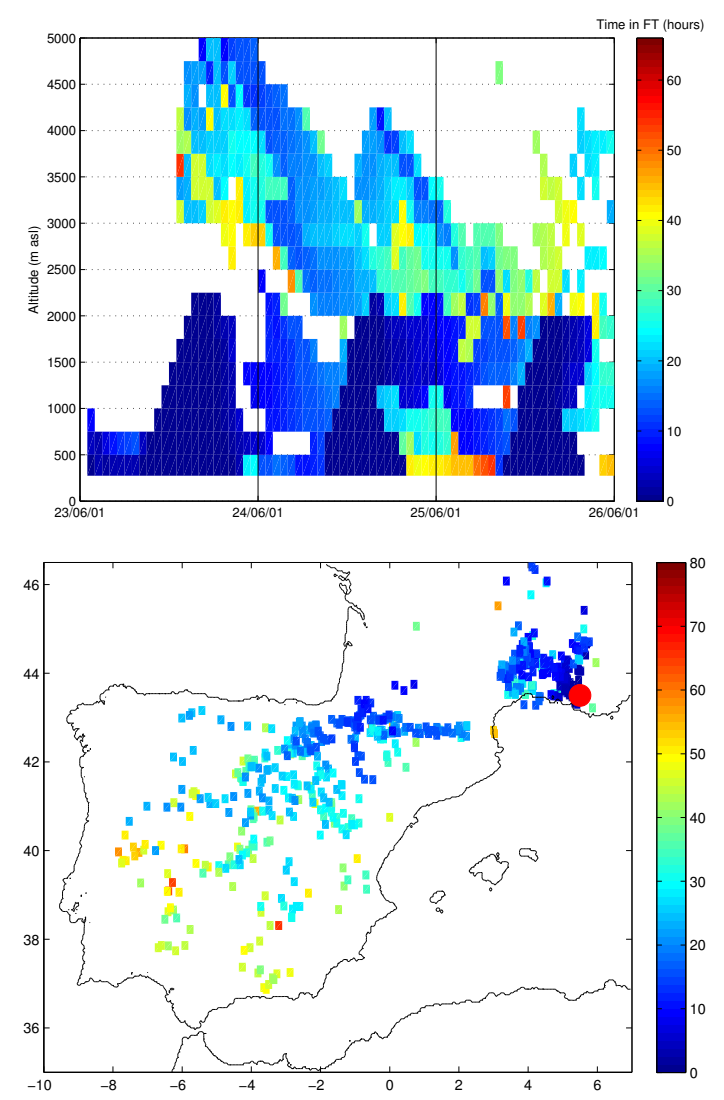

Fig. 3. Footprint of air masses with a PBL origin arriving above the ALTO measurement site according to the mesoscale backtrajectories. A square is plotted for each trajectory coming from the PBL. The color of the square corresponds to the time the air parcel spent in the free troposphere before arriving in the ESCOMPTE area. Top panel: squares are plotted at the ending point of the trajectory (time and altitude above the lidar); bottom panel: squares are plotted at the location of extraction from the PBL. A red circle is plotted at the ALTO measurement site.

mixing is somewhat supported by the heterogeneity revealed by our analysis. Low ozone concentrations measured by lidar on 23 June and in the morning of the 24th at moderate altitudes (around $1500 \mathrm{~m}$ ), correspond to air masses exempt from any PBL signature. These trajectories are coming from the troposphere above the Northern Atlantic Ocean which is consistent with their relatively low ozone content (Reeves et al., 2002). The same conclusion holds for high altitude air masses (above $3000 \mathrm{~m}$ ) observed in the afternoon of 24 June and 25 June. To sum up, this analysis shows that positive ozone anomalies observed by lidar above $1500 \mathrm{~m}$ a.s.l. between 23 June 12:00 UT and 25 June 23:00 UT are synchronized with air masses having undergone export from the PBL, while ozone depleted layers are associated to aged free tropospheric air masses.
In the following, we will attempt to quantify the ozone content of air masses exported from the PBL according to the trajectory analysis. Prior to this step, the precise fraction of lidar data corresponding to air masses transported from the Iberian PBL must be selected. Possible mismatches in the timing between the model and the observations prohibit a straightforward comparison (Methven et al., 2001). Methven et al. (2003) propose a correction procedure using complementary in situ measurements such as the specific humidity and the equivalent potential temperature; but in our case the only available quantities above the lidar are the ozone concentrations and the aerosol backscattering ratio. Using large scale FLEXPART simulations we ensured that neither long range transport of pollutants nor stratospheric intrusions did play any role. So ozone-rich layers whose temporal and spatial extension is similar to the PBL footprint given on Fig. 3 are selected as coming from the PBL (see the black contours on Fig. 2a). The only exception is found on 23 June when we discarded two layers (centered at $2500 \mathrm{~m}$ and $1500 \mathrm{~m}$ ) because we did not find any matching evidence of PBL export with the mesoscale model.

\subsubsection{Transport processes analysis}

Local processes play an important role in trace gases distribution in the ESCOMPTE area. In the framework of the campaign, Bastin et al. (2005), Kahltoff et al. (2005) or Puygrenier et al. (2005) propose analyses of PBL processes that may lead to an export to the FT. In this paper, we decided to focus on free tropospheric air masses extracted from the distant PBL, i.e. air masses that have undergone transport and transformation in the free troposphere.

Figure $3 \mathrm{~b}$ shows the very large variability of geographical origins of air masses arriving in the FT above the ALTO lidar. To synthesize the information and identify the main transport pathways, the trajectories were clustered using the k-means multivariate clustering technique (Mac Queen, 1967). Each trajectory is characterized by its date, latitude and longitude of extraction from the PBL, and its date and altitude of arrival. To maximize the consistency of the clusters of trajectories we imposed a high number of clusters (about 20).

The clusters are displayed on Fig. 4 in a similar way as on Fig. 3a. Here, colors and labels correspond to the clusters of trajectories and exclusively air masses extracted from the distant PBL are presented. This way, one can infer the relation between air masses arriving above the ALTO measurement site and clusters of air masses listed on Table 1. Table 1 summarizes the characteristics of each cluster of trajectories, including the date and approximate location of extraction. We find that export from the Iberian PBL occurred daily during this period and that these processes took place at very widespread locations above Spain. The consistency of the clusters can be inferred from the root mean square distance (RMS) between the locations of uptake from the PBL for the trajectories belonging to each cluster. The number of 


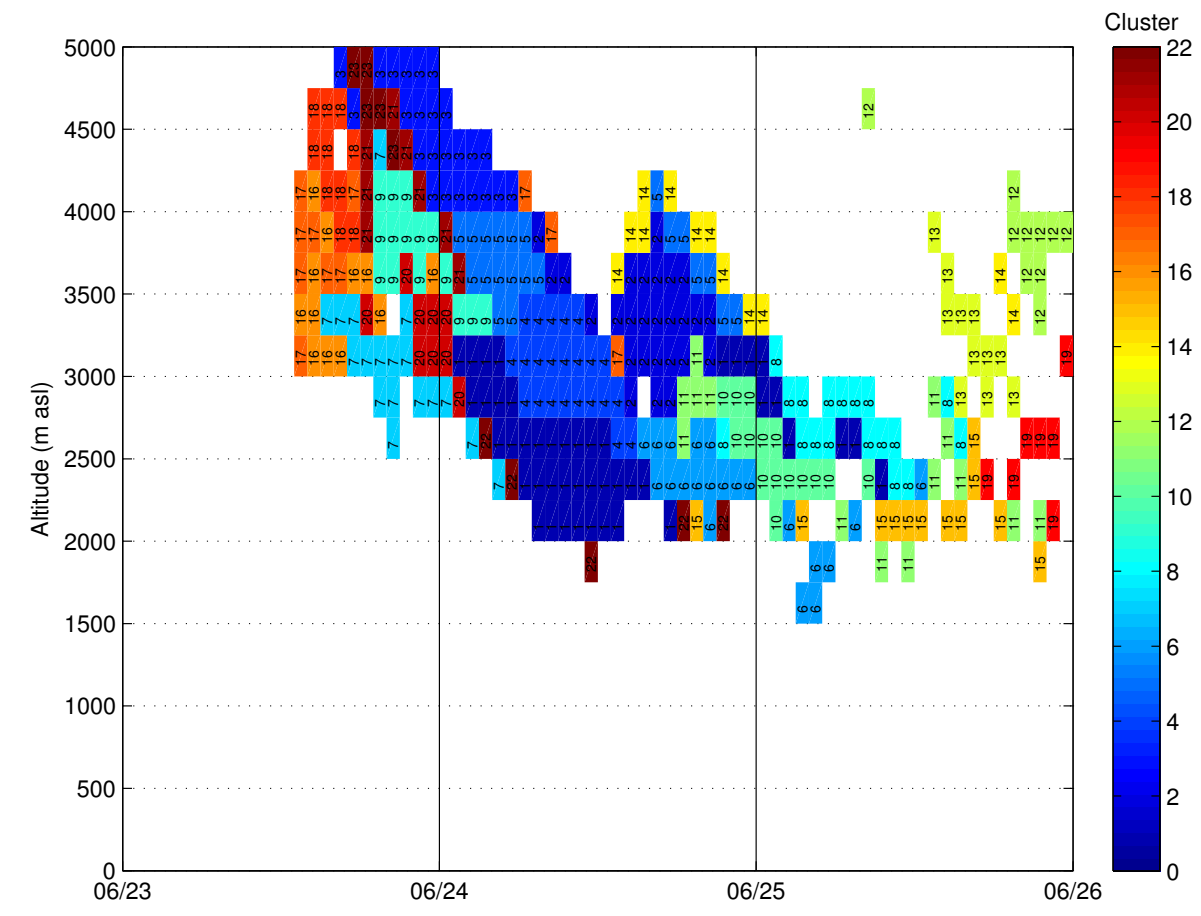

Fig. 4. Same as Fig. 3a for air masses extracted from the PBL outside of the ESCOMPTE region. Labels and color shading correspond to the references of the clusters of trajectories (see Table 1).

trajectories belonging to each cluster is also given to assess the significance of the clusters.

Modeled convective available potential energy (CAPE) is used to diagnose if convection could be responsible for the export to the FT. METEOSAT images suggest that convection did not organized in large MCS. Consequently in areas where modeled CAPE is high, export from the PBL remains limited to shallow convection. When CAPE levels are negligible, the most likely processes playing a role in the export to the free troposphere are thermal circulations. As mentioned in Sect. 2.3, depending on the location of export, these thermal circulations can be purely orographic, sea breezes, or a combination of both.

For most clusters, the export occurred in the afternoon when convection and thermal circulations reach their peak efficiency in terms of PBL venting. The only trajectories that left the PBL in the morning belong to clusters 3 to 6 . They correspond to air masses where ozone production is maximum as will be discussed in Sect. 3.5.

Using Eulerian chemistry simulations, Cousin et al. (2005) suggest that free tropospheric ozone variability measured by the ALTO lidar is influenced by air masses coming from the Barcelona area. The fact that they did not detect any transport processes from more distant places above Spain is probably related to the limited extent of their simulation domain. Dufour et al. (2005) propose another explanation for the free tropospheric ozone variability. They focus on CTM simula- tions and, by shutting down the two-way coupling between four nested domains, they discuss the origin of ozone-rich layers observed by the ALTO lidar on 24 and 25 June. They suggest stratospheric intrusions played an important role because some ozone-rich layers are not simulated when climatological boundary conditions are used above $5000 \mathrm{~m}$. In fact, an export from the PBL followed by tropospheric transport above $5000 \mathrm{~m}$ would give the same results. At the continental scale, the resolution of their CTM is similar to that of ECMWF analyses used in the FLEXPART simulation presented above. According to the FLEXPART model, many air masses coming from the Iberian PBL were indeed transported at about $5000 \mathrm{~m}$ of altitude.

\subsection{Trace gases concentrations in the Iberian PBL}

At this stage, we have shown a relationship between free tropospheric ozone-rich air masses observed in the ESCOMPTE area and modeled air masses exported from the Iberian PBL. The chemical composition of these air masses when they left the PBL can be evaluated using CTM simulations. In this study we used the model CHIMERE (version V200501G). 

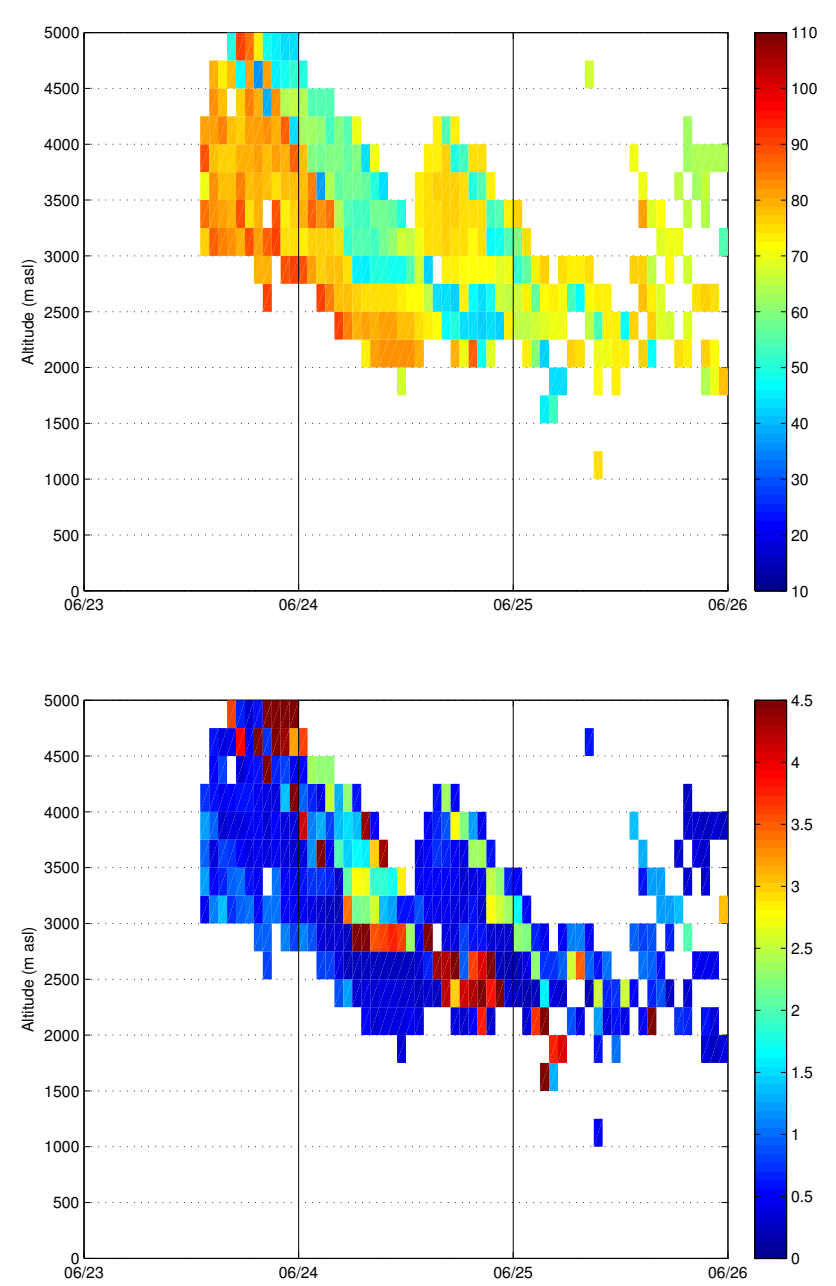

Fig. 5. Reverse domain filling of ozone (a) and $\mathrm{NO}_{\mathrm{x}}$ (b) concentrations (in ppbv) for air masses arriving above the ALTO lidar and coming from the Iberian PBL. Concentrations at the date and location of export from the PBL are interpolated from the CHIMERE simulation.

\subsubsection{Description of the CHIMERE model}

The model is described in Vautard et al. (2001) and the validation of continental scale simulations is given by Schmidt et al. (2001). The most up to date information regarding the model can be found at http://euler.lmd.polytechnique.fr/ chimere/.

The CTM is driven by MM5 meteorological fields (Vautard et al., 2005). Surface emissions are those of the annual EMEP inventory (http://www.emep.int) converted to hourly fluxes using the GENEMIS database (GENEMIS, 1994). The general circulation model LMDz-INCA (Hauglustaine et al., 2004) provides monthly means for the boundary conditions. The chemical mechanism is MELCHIOR (Lattuati, 1997) which includes 333 reactions of 82 gaseous species.

In the present simulation, the domain covers Western Europe with $67 \times 460.5$-degree wide horizontal grid cells. The vertical grid is hybrid sigma-pressure up to $350 \mathrm{hPa}$ with 30 levels ( 12 below $1 \mathrm{~km}$ ) and the timestep is $2.5 \mathrm{~min}$. The simulation runs continuously between 15 June and 29 June. In the following, CHIMERE outputs will be used to initialize the Lagrangian simulation. Good et al. (2003) warned that using CTM simulations with a T42 horizontal resolution to initialize a Lagrangian model induces spurious mixing of trace gases. However, this effect is minimized here, considering the 0.5 degree horizontal resolution of CHIMERE.

\subsubsection{Reverse domain filling of trace gases}

For each trajectory, at the latitude and longitude of extraction from the PBL we interpolate the concentration of 19 species: $\mathrm{O}_{3}$ (ozone), $\mathrm{H}_{2} \mathrm{O}_{2}$ (hydrogen peroxide), $\mathrm{NO}$ (nitric oxide), $\mathrm{NO}_{2}$ (nitrogen dioxide), $\mathrm{HONO}$ (nitrous acid), $\mathrm{HNO}_{3}$ (nitric acid), PAN (peroxyacetyl nitrate), CO (carbon monoxide), 
Table 1. Clusters of coherent mesoscale trajectories for air masses extracted from the Iberian PBL and arriving above the ALTO lidar. Reference of the clusters (same as Fig. 4), day, time, and altitude of arrival in the ESCOMPTE area and day, time, and location of extraction from the PBL, average RMS distance to the center of the cluster, number of trajectories belonging to each cluster, detection of high MesoNH CAPE levels at the date and location of extraction, and photochemical ozone production along the trajectory for the CiTTyCAT simulations selected in Sect. 3.4. Clusters with outstanding high and low production rates are highlighted in bold. The table is sorted depending on the date of extraction from the PBL.

\begin{tabular}{|c|c|c|c|c|c|c|c|c|c|c|}
\hline Cluster & $\begin{array}{c}\text { Arrive on } \\
\text { (DD/MM HH UT) }\end{array}$ & $\begin{array}{l}\text { Arrive at } \\
\mathrm{m} \text { (asl) }\end{array}$ & $\begin{array}{c}\text { Left PBL on } \\
\text { (DD/MM HH UT) }\end{array}$ & $\begin{array}{l}\text { Left PBL from: } \\
\text { (closest city) }\end{array}$ & $\begin{array}{l}\text { Left PBL from: } \\
\text { (lat,lon) }\end{array}$ & $\begin{array}{l}\text { RMS } \\
(\mathrm{km})\end{array}$ & N.traj & CAPE & $\begin{array}{l}\mathrm{P}\left(\mathrm{O}_{3}\right) \mathrm{REF} \\
\left(\mathrm{ppbvh}^{-1}\right)\end{array}$ & $\begin{array}{c}\mathrm{P}\left(\mathrm{O}_{3}\right) 3 \mathrm{NO}_{\mathrm{x}} \\
\left(\mathrm{ppbvh} \mathrm{h}^{-1}\right)\end{array}$ \\
\hline 7 & 23/06 20UT & 2958 & 21/06 18UT & Salamanca-Coimbra & $(-6.8 \mathrm{E}, 40.4 \mathrm{~N})$ & 90 & 18 & & 0.01 & 0.12 \\
\hline 17 & 23/06 19UT & 3613 & $21 / 0622 \mathrm{UT}$ & Cordoba - Badajoz & $(-5.3 \mathrm{E}, 38.4 \mathrm{~N})$ & 124 & 11 & & 0.00 & 0.11 \\
\hline 16 & 23/06 16UT & 3375 & 22/06 14UT & Galician coast & $(-4.5 \mathrm{E}, 42.7 \mathrm{~N})$ & 94 & 12 & & 0.05 & 0.13 \\
\hline 18 & 23/06 15UT & 4175 & 22/06 16UT & Salamanca & $(-6.3 \mathrm{E}, 41.1 \mathrm{~N})$ & 76 & 10 & & -0.05 & 0.05 \\
\hline 9 & 23/06 21UT & 3633 & 22/06 16UT & Zaragosa - Valencia & $(-1.4 \mathrm{E}, 40.8 \mathrm{~N})$ & 99 & 15 & yes & 0.02 & 0.08 \\
\hline 20 & 23/06 22UT & 3138 & 22/06 17UT & North Zaragosa & $(-0.2 \mathrm{E}, 42.4 \mathrm{~N})$ & 28 & 9 & yes & 0.04 & 0.12 \\
\hline 21 & 23/06 20UT & 4000 & 22/06 18UT & Madrid & $(-3.0 \mathrm{E}, 41.1 \mathrm{~N})$ & 78 & 8 & & 0.07 & 0.18 \\
\hline 23 & 23/06 18UT & 4550 & 22/06 21UT & Zaragosa & $(-1.5 \mathrm{E}, 41.2 \mathrm{~N})$ & 78 & 5 & yes & 0.18 & 0.13 \\
\hline 22 & 24/06 11UT & 2100 & 23/06 02UT & North Zaragosa & $(0.0 \mathrm{E}, 42.4 \mathrm{~N})$ & 58 & 5 & yes & 0.03 & 0.11 \\
\hline 11 & 25/06 06UT & 2357 & 23/06 04UT & Badajoz - Sevilla & $(-6.1 \mathrm{E}, 39.0 \mathrm{~N})$ & 72 & 14 & & -0.01 & 0.09 \\
\hline 3 & 23/06 23UT & 4354 & 23/06 08UT & Burgos - Pamplona & $(-1.8 \mathrm{E}, 42.6 \mathrm{~N})$ & 61 & 24 & & 0.31 & 0.40 \\
\hline 6 & $24 / 0622 \mathrm{UT}$ & 2154 & 23/06 08UT & Valadolid & $(-3.6 \mathrm{E}, 41.9 \mathrm{~N})$ & 63 & 21 & & 0.36 & 0.44 \\
\hline 4 & 24/06 09UT & 2923 & 23/06 09UT & Burgos & $(-2.4 \mathrm{E}, 42.5 \mathrm{~N})$ & 39 & 23 & & 0.27 & 0.35 \\
\hline 15 & 25/06 11UT & 2041 & 23/06 12UT & Madrid - Valencia & $(-2.4 \mathrm{E}, 39.8 \mathrm{~N})$ & 142 & 12 & & 0.14 & 0.21 \\
\hline 2 & 24/06 15UT & 3240 & 23/06 14UT & Valadolid & $(-3.4 \mathrm{E}, 41.5 \mathrm{~N})$ & 59 & 27 & yes & 0.09 & 0.21 \\
\hline 5 & 24/06 09UT & 3571 & 23/06 15UT & Burgos - Pamplona & $(-1.4 \mathrm{E}, 42.8 \mathrm{~N})$ & 76 & 21 & & 0.24 & 0.41 \\
\hline 1 & 24/06 12UT & 2472 & 23/06 16UT & SE Pyreneans & $(0.8 \mathrm{E}, 42.8 \mathrm{~N})$ & 64 & 45 & yes & 0.10 & 0.22 \\
\hline 10 & 25/06 01UT & 2400 & 23/06 16UT & Zaragosa & $(-1.6 \mathrm{E}, 40.8 \mathrm{~N})$ & 29 & 15 & yes & 0.03 & 0.21 \\
\hline 8 & 25/06 06UT & 2597 & 23/06 17UT & S Madrid & $(-4.2 \mathrm{E}, 40.1 \mathrm{~N})$ & 55 & 18 & & 0.07 & 0.16 \\
\hline 13 & 25/06 16UT & 3187 & 23/06 18UT & Granada & $(-3.8 \mathrm{E}, 37.3 \mathrm{~N})$ & 76 & 12 & & 0.04 & 0.18 \\
\hline 14 & $24 / 0622 \mathrm{UT}$ & 3604 & 23/06 20UT & W Madrid & $(-4.5 \mathrm{E}, 40.4 \mathrm{~N})$ & 76 & 12 & & 0.05 & 0.23 \\
\hline 12 & 25/06 20UT & 3846 & 24/06 14UT & North Granada & $(-3.0 \mathrm{E}, 38.8 \mathrm{~N})$ & 64 & 13 & & -0.03 & 0.07 \\
\hline 19 & 25/06 21UT & 2388 & 24/06 17UT & Zaragosa & $(-2.1 \mathrm{E}, 41.4 \mathrm{~N})$ & 72 & 9 & & 0.02 & 0.14 \\
\hline Average & & & & & & & & & $0.09 \pm 0.12$ & $0.19 \pm 0.11$ \\
\hline
\end{tabular}

$\mathrm{SO}_{2}$ (sulfur dioxide), $\mathrm{CH}_{4}$ (methane), $\mathrm{C}_{2} \mathrm{H}_{6}$ (ethane), $\mathrm{C}_{4} \mathrm{H}_{10}$ (butane), $\mathrm{C}_{2} \mathrm{H}_{4}$ (ethene), $\mathrm{C}_{3} \mathrm{H}_{6}$ (propene), $\mathrm{C}_{5} \mathrm{H}_{8}$ (isoprene), $\mathrm{HCHO}$ (formaldehyde), $\mathrm{CH}_{3} \mathrm{CHO}$ (acetaldehyde), $\mathrm{HCO}$ $\mathrm{CHO}$ (glyoxal), $\mathrm{CH}_{3} \mathrm{COCHO}$ (methylglyoxal). For our purpose, we must quantify the composition of air masses when they left the PBL. The mesoscale backtrajectories are used exclusively in the free troposphere, i.e. trajectories are considered to start at the top of the PBL. This way, we avoid accounting for mixing processes occurring when the air mass crosses the dynamical barrier constituted by the PBL top. However, since the updrafts did not necessarily started at the top of the PBL, the proxy we used for the composition of air masses exported to the free troposphere is the average of trace gases concentrations in the PBL at the location of export (here the depth of the PBL is given by the MM5 model).

Reverse domain filling (RDF) of ozone and $\mathrm{NO}_{\mathrm{x}}$ concentrations are displayed on Figs. 5a and b for each trajectory at the time and altitude of arrival in the ESCOMPTE area. On this figure we represent the composition that air masses had when they left the PBL. Using this RDF technique we find that some air masses have low ozone content, which do not match lidar observations. Most of these air masses are associated to high $\mathrm{NO}_{\mathrm{x}}$ levels. According to Fig. 4 and Table 1, these air masses left the PBL in the morning, i.e. when ozone production was not yet initiated, which explain their ozone and $\mathrm{NO}_{\mathrm{x}}$ load. After having left the PBL with high $\mathrm{NO}_{\mathrm{x}}$ concentrations, these air masses are advected for a couple of days in the free troposphere and ozone production is very likely to occur during the transport. Similar results are discussed by Lawrence et al. (2003). By redistributing exclusively ozone in convective systems, they find that convection has a negative effect on the total tropospheric ozone burden whereas if they include precursors, the convective transport induces an increase of background ozone. To sum up, this purely advective RDF approach does not yield a satisfactory comparison with the measurements and underlines the need to account for the photochemical transformation.

\subsection{Transport and transformation}

A more realistic comparison between observed and modeled ozone in air masses coming from the distant PBL will be achieved by accounting for the photochemical transformation along Lagrangian trajectories.

\subsubsection{Description of the CiTTyCAT model}

The Cambridge Tropospheric Trajectory model of Chemistry and Transport (CiTTyCAT) is a Lagrangian chemistry model designed to evaluate trace species transformation along prescribed trajectories. The model is described in Wild et al. (1996) and Evans et al. (2000). Reactions of $\mathrm{O}_{\mathrm{x}}, \mathrm{HO}_{\mathrm{x}}$ and $\mathrm{NO}_{\mathrm{x}}$ are included as well as methane oxidation and a parameterized hydrocarbon degradation scheme. The total number of species considered is 88 . Photolysis rates are computed using a two-stream method accounting for the effect of cloudiness on a climatological basis. Dry deposition is included but plays a limited role in the present simulations where air parcels are transported in the free troposphere. 


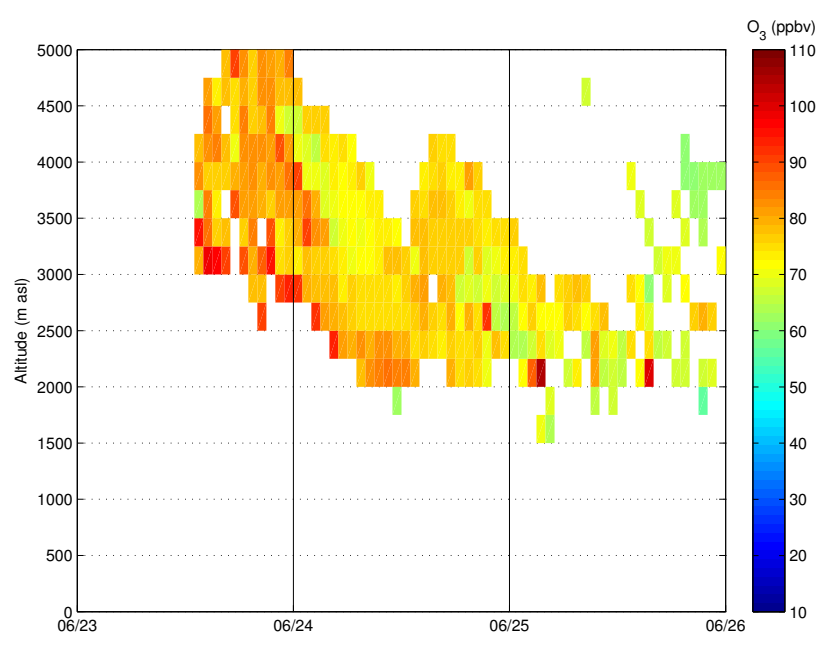

Fig. 6. Ozone concentrations simulated with the CiTTyCAT model for the reference run represented at the date and altitude of arrival of the air masses above the ALTO measurement site.

In this study, air masses follow MesoNH trajectories. Pressure, water content and temperature along the trajectories are interpolated from the mesoscale model. Initial chemical compositions of air masses are provided by CHIMERE simulations using the methodology presented in Sect. 3.2.2.

\subsubsection{Uncertainties of the chemical initialization}

Wild fires may influence trace gases concentrations of air masses exported from the PBL whereas they are not included in the CTM simulation that relies on climatological surface emissions. Forest fires could thus induce important uncertainties. Some forest fires were detected in Spain on 23 June as hot spots by the AVHRR instrument. However, these fires were not detected by the MODIS instrument. This difference may be due to different sensibilities and detection algorithms for small isolated fires. The instruments may also have flown above the area at different times and a cloud could have occulted fires for the MODIS instrument. In addition, these fires were not reported by the Global Fire Monitoring Center (http://www.fire.uni-freiburg.de/). Consequently, wild fires were limited in space and time and their impact on observed trace gases emissions and transport - e.g. through pyro-convective events - should remain very limited.

Chemical initialization plays an important role in ozone photochemical production. As described by Kleinman et al. (1997), ozone production is constrained by (1) the availability of NO, (2) the loss of hydroxyl radicals through recombination with $\mathrm{NO}_{2}$, and (3) production of $\mathrm{HO}_{\mathrm{x}}(=\mathrm{OH}$ $+\mathrm{HO}_{2}+\mathrm{RO}_{2}$ ). Reeves et al. (2002) have shown that, for low $\mathrm{NO}_{\mathrm{x}}$ concentrations, water vapor plays an important role. But, for the photochemical regimes explored here, ozone production will be driven at first order by $\mathrm{NO}_{\mathrm{x}}$ and
Volatile Organic Compounds (VOC) levels. Nevertheless, modeled water vapor mixing ratios and $\mathrm{NO}_{2}$ photolysis rates were checked against balloon borne and airborne observations in the ESCOMPTE area and showed a good agreement (not shown). Consequently, uncertainties related to the representation of water vapor and photolysis rates will remain limited.

On the contrary, significant biases were identified between $\mathrm{NO}_{2}$ concentrations given by the CHIMERE model in the Spanish PBL and surface measurements of the EMEP network. For the time period between 20th and 25th June, the temporal average of surface $\mathrm{NO}_{2}$ concentrations according to 7 Spanish stations of the EMEP network is $987 \mathrm{pptv}$ $(\sigma=559 \mathrm{pptv})$. While at the altitude and location of these stations, the CHIMERE model gives an average $\mathrm{NO}_{2}$ content of $441 \mathrm{pptv}(\sigma=205 \mathrm{pptv})$. Observational error as high as $25 \%$ (as reported by Schmidt et al., 2001) can not explain this discrepancy. A weakness of the emission model above Spain could be responsible for this gap. But the fact that this underestimation is more important at the stations located above $800 \mathrm{~m}$ a.s.l. suggests that the difficulty to represent correctly pollutants dispersion in mountainous area plays a role too. However, considering the size of the grid cells and the lifetime of $\mathrm{NO}_{\mathrm{x}}$ in the PBL, the reliability of comparison with surface stations remains limited. By means of a comparison between CHIMERE simulations and tropospheric $\mathrm{NO}_{2}$ columns measured by the GOME instrument (http://www.doas-bremen.de/), Konovalov et al. (2005) present similar results. Although they perform in strong assumptions on vertical distribution of $\mathrm{NO}_{2}$, they find that, on average for the summer of 2001, the model underestimates $\mathrm{NO}_{2}$ concentrations above Spain.

This underestimation should also be put in perspective with the study of Parrish et al. (2004), who report a systematic underestimation of trace species transport through shallow venting processes while deep convection transport is generally accurate in global CTMs. And such an underestimation of the venting of nitrogen oxides could lead to a premature ageing of air masses and thus bias the partitioning of $\mathrm{NO}_{\mathrm{y}}$ toward less $\mathrm{NO}_{\mathrm{x}}$. However, this hypothesis can not be checked against surface observations because of the lack of such data in the Spanish PBL.

Consequently, the main uncertainty of the chemical initialization will be related to initial $\mathrm{NO}_{\mathrm{x}}$ levels prescribed by the CHIMERE model. Therefore, we decided to explore an alternate initialization where initial $\mathrm{NO}_{\mathrm{x}}$ concentrations are artificially multiplied by a factor 3 . The comparisons discussed in the previous paragraph allowed to define the range of concentrations to be explored. And the fact that $\mathrm{NO}_{\mathrm{x}}$ underestimation at the top of the PBL could be due either to the emission inventory or to $\mathrm{NO}_{\mathrm{x}}$ venting in the PBL justified to adjust $\mathrm{NO}_{\mathrm{x}}$ levels at the top of the PBL rather than changing the emission inventory. However, multiplying $\mathrm{NO}_{\mathrm{x}}$ concentrations at the top of the PBL without changing secondary pollutants concentrations (such as ozone) is not 
realistic. And we also performed simulations with prescribed initial ozone concentrations perturbed of 5\%. Indeed, comparisons of ozone measured at the Spanish EMEP surface stations with the CHIMERE simulation are quite good. The average surface ozone measured is $69.1 \mathrm{ppbv}$ and the model gives 71.1 ppbv. These simulations will be used in Sect. 3.4.2 to quantify the uncertainties of the hybrid-Lagrangian reconstruction.

\subsubsection{Results of the Lagrangian photochemical simulation}

Modeled ozone concentrations at the ending point of the trajectories are presented on Fig. 6 and can be compared with lidar measurements of Fig. 2a. At this stage, mixing is not included, so that the air parcels are isolated from the surrounding environment.

Compared to the RDF approach discussed in Sect. 3.2.2, ozone concentration has increased in the main layer centered on $2500 \mathrm{~m}$ between 23 June and the morning of 25 June. Consequently the match between observed and modeled ozone is better. The high-ozone layer measured by the ALTO lidar on 24 June at 12:00 UT and centered around $2500 \mathrm{~m}$ is not reproduced, but the presence of a small cloud leads to an important uncertainty regarding this layer (Ancellet and Ravetta, 2005). For trajectories arriving during the afternoons of 23 and 25 June, ozone concentrations are similar to those presented on Fig. 5, suggesting that the net ozone production is very limited during the transport.

At the initialization of the hybrid Lagrangian simulation, average ozone and $\mathrm{NO}_{\mathrm{x}}$ concentrations prescribed by the CTM are $68.6 \mathrm{ppbv}(\sigma=12.8 \mathrm{ppbv})$ and $1350 \mathrm{pptv}$ $(\sigma=1650 \mathrm{pptv})$, respectively. Accounting for the photochemical transformation along the trajectories leads to ozone and $\mathrm{NO}_{\mathrm{x}}$ concentrations of $75.6 \mathrm{ppbv}(\sigma=7.2 \mathrm{ppbv})$ and $160 \mathrm{pptv}$ $(\sigma=84 \mathrm{pptv})$. According to the ALTO lidar, the average ozone content of air masses coming from the PBL (as defined in Sect. 3.1.2) is $72.9 \mathrm{ppbv}$ ( $\sigma=7.7 \mathrm{ppbv}$ ). Consequently, accounting for the photochemical transformation during the transport allows to compensate for the underestimation obtained with the RDF technique.

The large ozone anomaly was also reproduced successfully by the CHIMERE model itself, even though the average ozone content of this air mass was slightly overestimated: $75.3 \mathrm{ppbv}(\sigma=3.4 \mathrm{ppbv})$ and the variability of free tropospheric ozone was much lower than in the observations. But the Eulerian approach only give instantaneous pictures of ozone variability and does not allow to further investigate photochemical transformation of air masses during their transport as will be discussed below.

The average net ozone production rates within each cluster is given in Table 1. Ozone is produced in most air masses, although it is degraded in the free troposphere for $31 \%$ of trajectories. This proportion may appear as a quite large fraction of the air parcels, but this decrease is often very limited, only $5 \%$ of the trajectories exhibit an ozone decrease of more than $4.6 \mathrm{ppbv}$. Air parcels presenting such a decrease in ozone content were exported from the PBL with high initial ozone load and low $\mathrm{NO}_{\mathrm{x}}$, which suggest that ozone production occured in the PBL, before the transport to the free troposphere.

As mentioned in Sect. 3.3.2, we performed an additional simulation to assess the sensitivity of our results to prescribed initial $\mathrm{NO}_{\mathrm{x}}$ concentrations. In the additional run, initial $\mathrm{NO}_{\mathrm{x}}$ levels were multiplied by a factor 3 , the concentrations of the other species being kept constant. Then, ozone is produced along $96 \%$ of the trajectories; average ozone and $\mathrm{NO}_{\mathrm{x}}$ concentrations at the ending point of the trajectories are $80.7 \mathrm{ppbv}(\sigma=8.5 \mathrm{ppbv})$ and $430 \mathrm{pptv}(\sigma=1120 \mathrm{pptv})$, respectively.

Few free tropospheric $\mathrm{NO}_{\mathrm{x}}$ measurements were performed during the ESCOMPTE campaign and most of them present large uncertainties. According to Saïd et al. (2005), the most reliable measurements are those obtained with a luminol analyzer (Metair $\mathrm{NO}_{x} \mathrm{TO}_{y}$ ) on board a Dornier aircraft (Hasel et al., 2005) and with a chemiluminescence $\mathrm{NO}_{\mathrm{x}}$ analyzer (MONA) on board the ARAT aircraft (Marion et al., 2001). However the NOxTOy instrument is not designed for sampling free tropospheric $\mathrm{NO}_{\mathrm{x}}$ concentrations below $1 \mathrm{ppbv}$ so that we will use only MONA measurements in this study. The experimental setup during the ESCOMPTE campaign is given in Coll et al. (2005). Tropospheric profiles up to $3000 \mathrm{~m}$ above Avignon, Istres and offshore were performed on 23,24 and 25 June and show little variability, the average $\mathrm{NO}_{\mathrm{x}}$ profile for these three days is given on Fig. 7 as well as minimum and maximum values. Average $\mathrm{NO}_{\mathrm{x}}$ concentrations measured above $1500 \mathrm{~m}$ is $597 \mathrm{pptv}(\sigma=119 \mathrm{pptv})$. The modeled $\mathrm{NO}_{\mathrm{x}}$ concentrations for the reference run are way below this estimate while those of the enhanced $\mathrm{NO}_{\mathrm{x}}$ scenario, although still underestimated, are within the range of the observations. $\mathrm{NO}_{\mathrm{y}}$ measurements were also performed aboard the same aircraft. The model simulates an average $\mathrm{NO}_{\mathrm{y}}$ content of $6460 \mathrm{pptv}$ ( $\sigma=4800 \mathrm{pptv}$ ), which is clearly over-estimated compared to the observations: $1230 \mathrm{pptv}$ $(\sigma=160 \mathrm{pptv})$ above $1500 \mathrm{~m}$. Even though it is difficult to validate $\mathrm{NO}_{\mathrm{y}}$ modeling in the absence of $\mathrm{NO}_{\mathrm{y}}$ observations at the initialization of the trajectories, this over-estimation points toward the hypothesis of a flaw in $\mathrm{NO}_{\mathrm{y}}$ partitioning at the initialization. The impact of the $\mathrm{NO}_{\mathrm{y}}$ underestimation on the ozone phtochemical production should remain limited considering the slow reconversion of $\mathrm{HNO}_{3}$ and PAN into $\mathrm{NO}_{\mathrm{x}}$ during the relatively short timescale of the trajectories. Note also that the constrain posed by this comparison on the quality of the simulation is limited by the fact that model and observations are not co-localized. Therefore, we conclude that, if none of the simulations is optimal in terms of $\mathrm{NO}_{\mathrm{x}}$ budget, the enhanced $\mathrm{NO}_{\mathrm{x}}$ scenario, by approaching observed values, constitutes a good tradeoff.

To sum up, at this stage we obtained a realistic reconstruction of the photochemical transformation of selected air masses, although simulated ozone levels are overestimated 


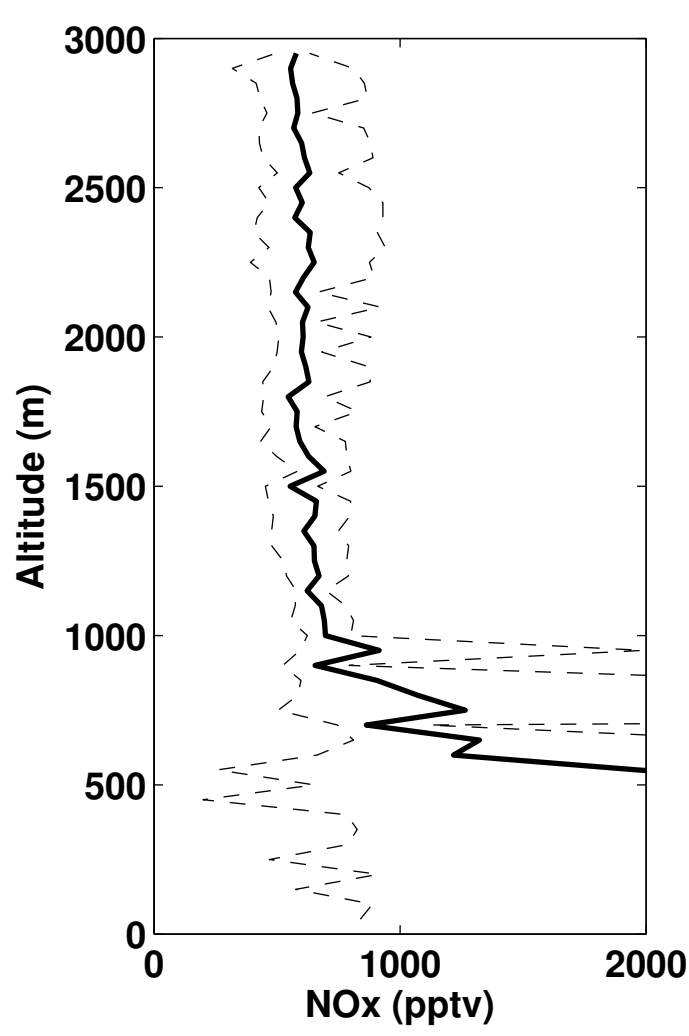

Fig. 7. $\mathrm{NO}_{\mathrm{x}}$ profiling with the MONA instrument on board the ARAT aircraft in the ESCOMPTE region. The average profile for the flights of the 23rd, 24th, and 25th of June is given (bold) as well as minimum and maximum values.

compared to lidar measurements. Consequently, we decided to account for the mixing with background air to achieve a better comparison with the observations.

\subsection{Impact of the mixing along the trajectories}

For both the reference run and the "enhanced $\mathrm{NO}_{\mathrm{x}}$ " scenario, the hybrid-Lagrangian model overestimates ozone concentrations. The fact that air parcels are isolated from the surrounding environment plays a role in this overestimation (Wild et al., 1996) and justifies the need to account for the mixing with background air.

\subsubsection{Methodology}

In this study, we chose to mix air parcels with a climatological background. The species concerned by this mixing are: $\mathrm{O}_{3}, \mathrm{H}_{2} \mathrm{O}_{2}, \mathrm{NO}, \mathrm{NO}_{2}, \mathrm{HONO}, \mathrm{HNO}_{3}, \mathrm{CO}, \mathrm{SO}_{2}, \mathrm{CH}_{4}, \mathrm{C}_{2} \mathrm{H}_{6}$, $\mathrm{C}_{4} \mathrm{H}_{10}, \mathrm{C}_{2} \mathrm{H}_{4}, \mathrm{C}_{3} \mathrm{H}_{6}$ and PAN. A test case where mixing was limited to ozone showed that the impact of mixing of the other constituents was limited. The strength of the mixing is characterized by a characteristic time, i.e. the e-folding time necessary to reach background concentrations if the composition of air parcels were exclusively subject to the mixing.
The relaxation field is a climatology corresponding to the three-dimensional average of CHIMERE outputs between 15 June and 25 June. The average free tropospheric ozone concentration along trajectories coming from the Spanish PBL is $64.7 \mathrm{ppbv}(\sigma=7.8 \mathrm{ppbv})$ which is in the range of the climatology based on balloon soundings proposed by Logan (1999). The purpose of this parameterization of the mixing is to account for the interactions with background air. That is why the relaxation field is climatological. Mixing with time dependant 3-D CHIMERE outputs would make sense if one would expect that the trajectory encountered an European polluted plume that was simulated by CHIMERE, while the MesoNH model would have missed the mixing of air masses with distinct origins. However, considering the resolution of the semi-Lagrangian trajectories, such an event would have been detected in the analysis of transport processes.

The mean and standard deviation of modeled ozone distributions as well as average $\mathrm{NO}_{\mathrm{x}}$ concentrations are given on Fig. 8 for characteristic mixing times between half a day and 7 days. Results of the no-mixing runs and measured ozone and $\mathrm{NO}_{\mathrm{x}}$ concentrations are also given.

\subsubsection{Results}

Modeled and observed standard deviations of ozone are given on Fig. 8c. Figure 8d displays the Fisher test used for comparing the standard deviation of two populations when their mean is not known and the 95\% confidence level (Bevington and Robinson, 1992). The reference is the ALTO record. The standard deviation of ozone distributions in CiTTyCAT outputs decreases with the characteristic mixing time since concentrations are relaxed toward a climatological 3-D field. Increasing initial $\mathrm{NO}_{\mathrm{x}}$ concentrations tend to produce more ozone in air masses where $\mathrm{NO}_{\mathrm{x}}$ levels were already significant. Consequently, standard deviations for these high$\mathrm{NO}_{\mathrm{x}}$ simulations are higher. For the enhanced $\mathrm{NO}_{\mathrm{x}}$ scenario, the mixing time should not be faster than about 2.5 days for the standard deviation of ozone to remain statistically similar to that measured by the lidar. For the reference simulation, the modeled and measured standard deviations become similar if the mixing time is larger than 5.5 days.

Average ozone concentrations are displayed on Fig. 8a. The Student t-test and its $95 \%$ confidence level are given on Fig. 8b, the reference being the ALTO estimate. Again, we find that average ozone concentrations are overestimated for no-mixing CiTTyCAT runs. Accounting for the mixing makes average ozone more realistic. Nonetheless for the enhanced $\mathrm{NO}_{\mathrm{x}}$ scenario, it is not statistically similar to measured ozone concentrations if mixing time differs from 1.5 to 2.5 days. For the reference run, mixing times included in the 3 to 7 days range give satisfactory results.

To sum up, the optimum between average and standard deviation of modeled ozone is reached for a characteristic mixing time of 6 and 2.5 days depending on the initial $\mathrm{NO}_{\mathrm{x}}$ concentrations considered. As mentioned above, important 

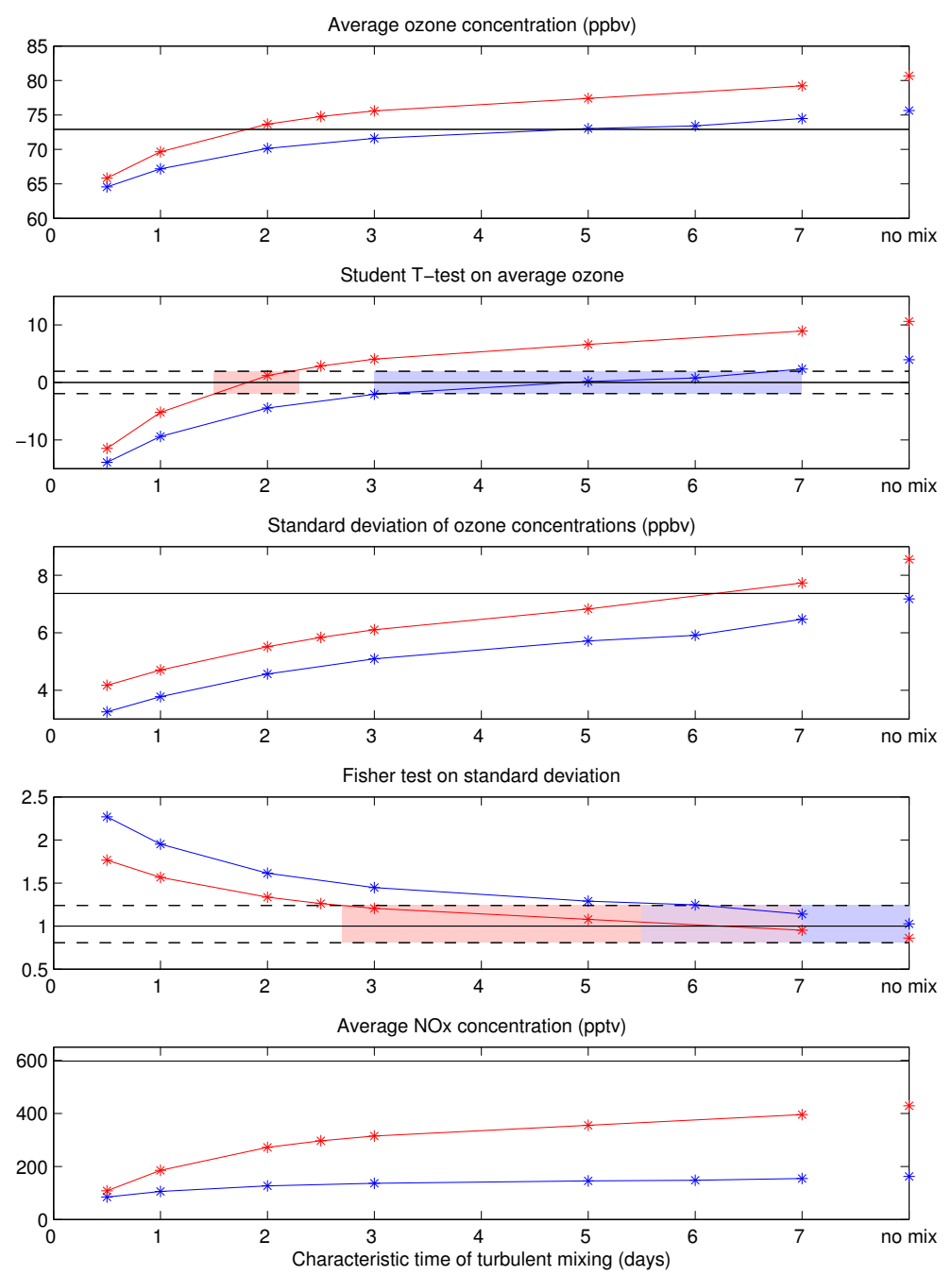

Fig. 8. Average and standard deviation of ozone concentrations $(\mathbf{a}, \mathbf{c})$ and average $\mathrm{NO}_{\mathrm{x}}(\mathbf{e})$ modeled with the hybrid-Lagrangian model for different characteristic time of turbulent mixing. For the reference run (blue) and the enhanced initial $\mathrm{NO}_{\mathrm{x}} \mathrm{scenario}$ (red). Results of no-mixing simulations are also displayed as well as observations (black, ALTO for ozone and MONA for $\mathrm{NO}_{\mathrm{x}}$ ). Panels (b) and (d) present statistical tests for the validity of the comparison with the ALTO record with 95\% confidence levels (dashed). The shaded areas correspond to optimum mixing times for the reference (blue), the enhanced $\mathrm{NO}_{\mathrm{x}}$ simulations (red), or both (violet).

uncertainties exist regarding the $\mathrm{NO}_{\mathrm{x}}$ levels at the initialization of the trajectories. For all the scenarios investigated, modeled $\mathrm{NO}_{\mathrm{x}}$ concentrations are below the average measured $\mathrm{NO}_{\mathrm{x}}$ concentrations (Fig. 8e). Nonetheless, results are much more realistic in the enhanced $\mathrm{NO}_{\mathrm{x}}$ cases than in the reference runs.

Now that we have identified the best simulations, we will be able to quantify ozone production efficiency during the transport in the free troposphere. Before proceeding to this analysis, we must assess uncertainties on mixing time discussed here above. First, as we mentioned in Sect. 3.3.2, simulations with a $5 \%$ change in initial ozone concentrations were performed. These simulations yield to a $2.5 \mathrm{ppbv}$ difference at the ending point of the trajectory for the enhanced
$\mathrm{NO}_{\mathrm{x}}$ scenario. According to Fig. 8a, this difference corresponds to an uncertainty smaller than 1 day on the characteristic mixing time. Second, a 5\% change in the ozone climatological background leads to a 0.2 day change in the characteristic mixing time (because the relaxation toward the climatological field follows an exponential law). We can thus conclude that the uncertainty on the characteristic mixing time is about 1 day.

\subsection{Ozone production efficiency}

Net ozone production $\left(\mathrm{P}\left(\mathrm{O}_{3}\right)\right)$ along the trajectories can be inferred from photochemical ozone production and loss during the transport as modeled by CiTTyCAT. For the reference simulation the optimum mixing time is 6 days (Sect. 3.4.2). 
With this value, we find an average ozone production rate of $0.09 \mathrm{ppbv} \mathrm{h}^{-1}\left(\sigma=0.12 \mathrm{ppbv} \mathrm{h}^{-1}\right)$. However, if ozone concentrations are satisfactory in the reference run, $\mathrm{NO}_{\mathrm{x}}$ levels are underestimated. Consequently, the average production rate of $0.19 \mathrm{ppbvh}^{-1}\left(\sigma=0.11 \mathrm{ppbvh}^{-1}\right)$ obtained with a mixing time of 2.5 days in the enhanced $\mathrm{NO}_{\mathrm{x}}$ scenario is probably a better estimate.

Production rates in the clusters of trajectories are given on Table 1 for both simulations. The clusters behave similarly when increasing initial $\mathrm{NO}_{x}$ concentration, i.e. $\mathrm{P}\left(\mathrm{O}_{3}\right)$ increases in every cluster. One exception is found for cluster 23 because (1) its initial $\mathrm{NO}_{\mathrm{x}}$ is already very high (Fig. 5b), allowing to switch to a $\mathrm{NO}_{\mathrm{x}}$ saturated regime as described in Sillman (1999) and (2) this cluster is of little significance with only 5 trajectories (Table 1 ). For some clusters, production rates stand out of the distribution, i.e. are greater or smaller than the average plus or minus one standard deviation. In clusters $3,4,5$ and 6 , production is very high (about $0.4 \mathrm{ppbv}^{-1}$ for the enhanced $\mathrm{NO}_{\mathrm{x}}$ scenario). Trajectories belonging to these clusters were exported toward the FT in the morning with high initial $\mathrm{NO}_{\mathrm{x}}$ and moderate ozone concentrations, paving the way for high ozone production during free tropospheric transport. Such ozone production levels are comparable to those found by Evans et al. (2000) and Methven et al. (2003) for polluted air masses associated to recent export from the PBL. Low production rates (net destruction of ozone) are found in clusters 12 and 18. These trajectories were exported from the PBL in areas of low emissions according to CHIMERE (around Salamanca and North of Granada).

On average for all the trajectories, the initial ozone concentration when air masses left the Iberian PBL was $68.6 \mathrm{ppbv}(\sigma=12.8 \mathrm{ppbv})$. The final average concentration above the ESCOMPTE area is $74.7 \mathrm{ppbv}(\sigma=5.8 \mathrm{ppbv})$ according to the enhanced $\mathrm{NO}_{\mathrm{x}}$ run with a 2.5 day mixing time. Consequently, $6.1 \mathrm{ppbv}$ of ozone are produced in the free troposphere. If the tropospheric ozone burden for this period is approximated as the average ozone concentrations measured by lidar above $2000 \mathrm{~m}$, we find a background level of 61.4 ppbv. We can thus conclude that PBL venting is responsible for an increase of $13.3 \mathrm{ppbv}$ of free tropospheric ozone concentrations, about $45 \%$ of this increase being related to photochemical production during the transport. Accounting for the 1 day uncertainty on the optimum mixing time discussed above, we find the contribution of free tropospheric production of the order of $30 \%$ to $50 \%$ (38 to $45 \%$ for the reference run). Using a global CTM, Liang et al. (1998) found that, on an annual basis, ozone production in the free troposphere is twice as large as direct export for the American PBL. The comparison of our approach (small scale, and limited to the ESCOMPTE period and location) to an annual estimate with a global model can only be used to put our results in a broader perspective. But both approaches lead to highlighting the need to account for ozone photochemical production during the transport in the free troposphere.

\section{Conclusion}

The free tropospheric ozone variability observed by lidar during the ESCOMPTE campaign was investigated by means of a hybrid-Lagrangian modeling study. The purpose of this work was to document the respective impact of transport and transformation on the observed free tropospheric ozone variability.

High-resolution backtrajectories were computed using a mesoscale model including semi-Lagrangian tracking of air parcels. Ozone-rich layers are related to air masses extracted recently from the Iberian PBL. A similar synoptic situation was discussed by Millán et al. (1997) who reports that export from the Iberian PBL occurs through local scale circulations (sea-breezes and orographic winds or a combination of both) or convective activity. The chemical composition of air masses when they left the PBL was inferred from CTM simulations. Comparison with the observations shows that photochemical transformation in the troposphere can not be neglected.

This transformation was modeled using a Lagrangian chemistry model which allowed simulating successfully the large ozone rich anomalies measured by lidar. One of the remarkable features is the fact that the shape and the ozone content of the large ozone-rich layer measured between the afternoon of 23 June and the morning of 25 June are well reproduced. We found that this event was constituted of air masses coming from widespread locations above Spain and their initial trace gases composition showed a high variability. Nevertheless, when these air masses reach the ESCOMPTE area they appear (according to both the measurement and the Lagrangian reconstruction) as a single layer with relatively homogeneous ozone content.

Different scenarios regarding initial $\mathrm{NO}_{\mathrm{x}}$ concentrations were investigated to achieve a satisfactory comparison with ozone and $\mathrm{NO}_{\mathrm{x}}$ measurements performed during the ESCOMPTE campaign. Modeled ozone concentrations are overestimated if mixing with background air is neglected. The optimum simulations are found for a characteristic mixing time of the order of 6 and 2.5 days for the reference run and the enhanced $\mathrm{NO}_{\mathrm{x}}$ scenario (initial $\mathrm{NO}_{\mathrm{x}}$ levels multiplied by a factor 3 ), respectively. The uncertainty regarding these mixing times is about 1 day.

According to the simulation based on the optimum mixing time, ozone is produced during the transport for the majority of air masses. Ozone production efficiency is highest for air masses that left the PBL in the morning $\left(0.4 \mathrm{ppbv} \mathrm{h}^{-1}\right)$, i.e. before photochemical transformation began in the PBL. On average, ozone production rate during the transport is of the order of $0.2 \mathrm{ppbv} \mathrm{h}^{-1}$; that is an $13.3 \mathrm{ppbv}$ increase during the transport in the free troposphere.

We found that the contribution of ozone produced in the free troposphere is at most as important as direct export of ozone in the PBL. These two processes are responsible for about $45 \%$ and $55 \%$ of the ozone increase related to PBL 
venting, respectively. During this event, we sampled air masses coming from widespread locations above Spain and at different times of the day. We can thus conclude that the Spanish PBL was a net exporter of ozone and of its precursors to the free troposphere during that period.

Acknowledgements. We thank all the participants to the ESCOMPTE campaign that contributed to the gathering of an impressive dataset, and especially P. Perros for $\mathrm{NO}_{\mathrm{x}}$ measurments and the EPFL team for ozone lidar profiling. The MesoNH team is gratefully acknowledged for assistance with the code (F. Gheusi, J. Escobar). R. Vautard provided MM5 simulations to drive CHIMERE simulations. Inputs for the CHIMERE model were provided by EMEP (yearly totals), IER (time variations), TNO (aerosol emissions), and UK Department of Environment (VOC speciation). A. Stohl gave helpful advices regarding the FLEXPART model. E. Real is also acknowledged for assistance regarding CiTTyCAT. EUMETSAT granted access to satellite imagery. Meteorological analyses were provided by ECMWF. This work was funded in part by Total (C. Puel and O. Duclaux).

Edited by: H. Wernli

\section{References}

Ancellet, G. and Ravetta, F.: A compact airborne lidar for tropospheric ozone (ALTO): description and field measurements, Appl. Opt., 37, 5509-5521, 1998.

Ancellet, G. and Ravetta, F.: Analysis and validation of ozone variability observed by lidar during the ESCOMPTE-2001 campaign, Atmos. Res., 74, 435-459, 2005.

Bastin, S. and Drobinski, P.: Sea breeze induced mass transport over complex terrain in southeastern France: A case study, Quart. J. Roy. Met. Soc., 132, 405-423, 2006.

Bastin, S., Drobinski, P., Dabas, A., Delville, P., Reitebuch O., and Werner, C.: Impact of the Rhône and Durance valleys on seabreeze circulation in the Marseille area, Atmos. Res., 74, 303328, 2005.

Bernsten, T. K., Isaksen, I. S. A., Myhre, G., Fuglestvedt, J. S., Stordal, F., Larsen, T. A., Freckleton, R. S., and Shine, K. P.: Effects of anthropogenic emissions on tropospheric ozone and its radiative forcing, J. Geophys. Res., 102, 28 101-28 126, 1997.

Bevington, P. R. and Robinson, D. K.: Data reduction and error analysis for the physical sciences, 2nd edition, McGraw-Hill Book Co, New York, USA, 328 p., 1992.

Coll I., Pinceloup, S., Perros, P. E., Laverdet, G., and Le Bras, G.: 3D analysis of the High Ozone Production Rates observed during the ESCOMPTE campaign, J. Atmos. Res., 74, 477-505, 2005.

Cooper, O. R., Moody, J. L., Parrish, D. D., Trainer, M., Ryerson, T. B., Holloway, J. S., Hubler, G., Fehsenfel, F. C., and Evans, M. J.: Trace gas composition of midlatitude cyclones over the western North Atlantic Ocean: A conceptual model, J. Geophys. Res., 107(D7), doi:10.1029/2001JD000901, 2002.

Corsmeier, U., Behrendt, R., Drobinski P., and Kottmeier, C.: The mistral and its effect on air pollution transport and vertical mixing, Atmos. Res., 74, 275-302, 2005.

Cotton, W. R., Alexander, G. D., Hertenstein, R., Walko, R. L., McAnelly, R. L., and Nicholls, M.: Cloud venting, A review and some new global annual estimates, Earth-Sci. Rev., 39(3-4), 169-206, 1995.

Cousin, F., Tulet, P., and Rosset, R.: Interaction between local and regional pollution during ESCOMPTE 2001: impact on surface ozone concentrations (IOP2a and 2b), Atmos. Res., 74, 117-137, 2005.

Cros, B. and Durand, P.: Preface, Guest editors, Atmos. Res., 74(14), 2005.

Cros, B., Durand, P., Cachier, H., Drobinski, P., Fréjafon, E., Kottmeier, C., Perros, P. E., Peuch, V.-H., Ponche, J.-L., Robin, D., et al.: The ESCOMPTE program: an overview, Atmos. Res., 69, 241-279, 2004.

Dufour, A., Amodei, M., Ancellet, G., and Peuch, V.-H.: Observed and modelled "chemical weather" during ESCOMPTE, Atmos. Res., 74, 161-189, 2005.

Eckhardt, S., Stohl, A., Beirle, S., Spichtinger, N., James, P., Forster, C., Junker, C., Wagner, T., Platt, U., and Jennings, S. G.: The North Atlantic Oscillation controls air pollution transport to the Arctic, Atmos. Chem. Phys., 3, 1769-1778, 2003, http://www.atmos-chem-phys.net/3/1769/2003/.

ECMWF: User Guide to ECMWF Products 2.1, Meteorological Bulletin M3.2, ECMWF, Reading, UK, 49 p., 1995.

Evans, M. J., Shallcross, D. E., Law, K. S., Wild, J. O. F., Simmonds, P. G., Spain, T. G., Berrisford, P., Methven, J., Lewis, A. C., McQuaid, J. B., Pillinge, M. J., Bandyf, B. J., Penkettf, S. A., and Pyle, J. A.: Evaluation of a Lagrangian box model using field measurements from EASE (Eastern Atlantic Summer Experiment) 1996, Atmos. Environ., 34(23), 3843-3863, 2000.

Gangoiti, G., Millán, M. M., Salvador, R., and Mantilla, E.: Longrange transport and re-circulation of pollutants in the western Mediterranean during the project Regional Cycles of Air Pollution in the West-Central Mediterranean Area, Atmos. Environ., 35(36), 6267-6276, 2001.

GENEMIS: Generation of European Emission Data for Episodes project, EUROTRAC annual report 1993, part 5, EUROTRAC international scientific secretariat, Garmisch-Partenkirchen, Germany, 1994.

Gheusi, F. and Stein, J.: Lagrangian description of airflows using Eulerian passive tracers, Quart. J. Roy. Met. Soc., 128, 337-360, 2002.

Gheusi, F., Cammas, J. -P., Cousin, F., Mari, C., and Mascart, P.: Quantification of mesoscale transport across the boundaries of the free troposphere: a new method and applications to ozone, Atmos. Chem. Phys. Discuss., 4, 8103-8139, 2004, http://www.atmos-chem-phys-discuss.net/4/8103/2004/.

Good, P., Giannakopoulos, C., O'Connor, F. M., Arnold, S. R., de Reus, M., and Schlager, H.: Constraining tropospheric mixing timescales using airborne observations and numerical models, Atmos. Chem. Phys., 3, 1023-1035, 2003, http://www.atmos-chem-phys.net/3/1023/2003/.

Hasel, M., Kottmeier, C., Corsmeier, U., and Wieser, A.: Airborne measurements of turbulent trace gas fluxes and analysis of eddy structure in the convective boundary layer over complex terrain, Atmos. Res., 74, 381-402, 2005.

Hauf, T., Schulte, P., Alheit, R., and Schlager, H.: Rapid vertical trace gas transport by an isolated midlatitude thunderstorm, J. Geophys. Res., 100(D11), 22 957-22 970, 1995.

Hauglustaine, D. A., Hourdin, F., Jourdain, L., Filiberti, M.A., Walters, S., Lamarque, J.-F., and Holland, E. A.: In- 
teractive chemistry in the Laboratoire de Météorologie Dynamique general circulation model: Description and background tropospheric chemistry evaluation, J. Geophys. Res., 109, doi:10.1029/2003JD003957, 2004.

Henne, S., Furger, M., Nyeki, S., Steinbacher, M., Neininger, B., deWekker, S. F. J., Dommen, J., Spichtinger, N., Stohl, A., and Prévôt, A. S. H.: Quantification of topographic venting of boundary layer air to the free troposphere, Atmos. Chem. Phys., 4, 497509, 2004,

http://www.atmos-chem-phys.net/4/497/2004/.

Kalthoff, N., Kottmeier, C., Thürauf, J., Corsmeier, U., Saïd, F., Fréjafon, E., and Perros, P. E.: Mesoscale circulation systems and ozone concentrations during ESCOMPTE: a case study from IOP 2b, Atmos. Res., 74, 355-380, 2005.

Kleinman, L. I., Daum, P. H., Lee, J. H., Lee, Y.-N., Nunnermacker, L. J., Springston, S. R., Newman, L., Weinstein-Lloyd, J., and Sillman, S., Dependence of ozone production on NO and hydrocarbons in the troposphere, Geophys. Res. Lett., 24(18), 2299-2302, doi:10.1029/97GL02279, 1997.

Konovalov, I. B., Beekmann, M., Vautard, R., Burrows, J. P., Richter, A., Nüß, H., and Elansky, N.: Comparison and evaluation of modelled and GOME measurement derived tropospheric NO2 columns over Western and Eastern Europe, Atmos. Chem. Phys., 5, 169-190, 2005,

http://www.atmos-chem-phys.net/5/169/2005/.

Lafore, J.-P., Stein, J., Asencio, N., Bougeault, P., Ducrocq, V., Duron, J., Fischer, C., Héreil, P., Mascart, P., Masson, V., Pinty, J.-P., Redelsperger, J.-L., Richard, E., and Vilà-Guerau de Arellano, J.: The Meso-NH Atmospheric Simulation System. Part I: adiabatic formulation and control simulations. Scientific objectives and experimental design, Ann. Geophys., 16, 90-109, 1998, http://www.ann-geophys.net/16/90/1998/.

Lattuati, M.: Contribution à l'étude du bilan de l'ozone troposphérique à l'interface de l'Europe et de l'Atlantique Nord: Modélisation lagrangienne et mesures en altitude, Ph.D. Thesis, Université Paris 6, Paris, 1997.

Lawrence, M. G., Von Kuhlmann, R., Salzmann, M., and Rasch, P. J.: The balance of effects of deep convective mixing on tropospheric ozone, Geophys. Res. Lett., 30(18), doi:10.1029/2003GL017644, 2003.

Lelieveld, J., Berresheim, H., Borrmann, S., Crutzen, P. J., Dentener, F. J., Fischer, H., Feichter, J., Flatau, P. J., Heland, J., Holzinger, R., Korrmann, R., Lawrence, M. G., Levin, Z., Markowicz, K. M., Mihalopoulos, N., Minikin, A., Ramanathan, V., de Reus, M., Roelofs, G. J., Scheeren, H. A., Sciare, J., Schlager, H., Schultz, M., Siegmund, P., Steil, B., Stephanou, E. G., Stier, P., Traub, M., Warneke, C., Williams, J., and Ziereis, H.: Global Air Pollution Crossroads over the Mediterranean, Science, 298(5594), 794-799, 2002.

Liang, J., Horowitz, L. W., Jacob, D. J., Wang, Y., Fiore, A. M., Logan, J. A., Gardner, G. M., and Munger, J. W.: Seasonal budgets of reactive nitrogen species and ozone over the United States, and export fluxes to the global atmosphere, J. Geophys. Res., 103(D11), doi:10.1029/97JD03126, 1998.

Logan, J. A.: An analysis of ozonesonde data for the troposphere: Recommendations for testing 3-D models and development of a gridded climatology for tropospheric ozone, J. Geophys. Res., 104(D13), doi:10.1029/1998JD100096, 1999.

MacQueen, J.: Some methods for classification and analysis multi- variate observations, 5th Berkeley Symposium of Mathematical Statistics and Probability 1, 281-297, 1967.

Marion, T., Perros, P. E., Losno, R., and Steiner, E.: Ozone Production Efficiency in Savanna and Forested Areas during the EXPRESSO Experiment, J. Atmos. Chem., 38(1), doi:10.1023/A:1026585603100, 2001.

Methven, J., Evans, M., Simmonds, P., and Spain, G.: Estimating relationships between air mass origin and chemical composition, J. Geophys. Res., 106(D5), 5005-5020, 2001.

Methven, J., Arnold, S. R., O'Connor, F. M., Barjat, H., Dewey, K., Kent, J., and Brough, N.: Estimating photochemically produced ozone throughout a domain using flight data and a Lagrangian model, J. Geophys. Res., 108(D9), doi:10.1029/2002JD002955, 2003.

Millán, M. M., Salvador, R., Mantilla, E., and Kallos, G.: Photooxidant dynamics in the Mediterranean basin in summer: Results from European research projects, J. Geophys. Res., 102(D7), doi:10.1029/96JD03610, 1997.

Norton, W. A.: Breaking Rossby Waves in a Model Stratosphere Diagnosed by a Vortex-Following Coordinate System and a Technique for Advecting Material Contours, J. Atmos. Sci., 51, 654673, 1994.

Parrish, D. D., Ryerson, T. B., Holloway, J. S., Neuman, J. A., Roberts, J. M., Williams, J., Stroud, C. A., Frost, G. J., Trainer, M., Hübler, G., Fehsenfeld, F. C., Flocke, F., and Weinheimer, A. J.: Fraction and composition of NOy transported in air masses lofted from the North American continental boundary layer, J. Geophys. Res., 109, D09302, doi:10.1029/2003JD004226, 2004.

Puygrenier, V., Lohou, F., Campistron, B., Saïd, F., Pigeon, G., Bénech, B., and Serça, D.: Investigation on the fine structure of sea-breeze during ESCOMPTE experiment, Atmos. Res., 74, 329-353, 2005.

Reeves, C. E., Penkett, S. A., Bauguitte, S., Law, K. S., Evans, M. J., Bandy, B. J., Monks, P. S., Edwards, G. D., Phillips, G., Barjat, H., Kent, J., Dewey, K., Schmitgen, S., and Kley, D.: Potential for photochemical ozone formation in the troposphere over the North Atlantic as derived from aircraft observations during ACSOE, J. Geophys. Res., 107(D23), doi:10.1029/2002JD002415, 2002.

Saïd, F., Corsmeier, U., Kalthoff, N., Kottmeier, C., Lothon, M., Wieser, A., Hofherr, T., and Perros, P. E.: ESCOMPTE experiment: intercomparison of four aircraft dynamical, thermodynamical, radiation and chemical measurements, Atmos. Res., 74, 217-252, 2005.

Schmidt, H., Derognat, C., Vautard, R., and Beekmann, M.: A comparison of simulated and observed ozone mixing ratios for the summer of 1998 in Western Europe, Atmos. Environ., 35(36), 6277-6297, 2001.

Sillman, S.: The relation between ozone, NOx and hydrocarbons in urban and polluted rural environments, Atmos. Env., 33, 18211845, 1999.

Simeonov, P., Ristori, P., Balin, I., Calpini, B., and van den Bergh, H.: A new DIAL based on a N2 Raman converter for ozone monitoring; design and application during the ESCOMPTE Campaign, Proc. of the XX Quaternary Ozone Symposium, Greece, 109-110, 2004.

Stohl, A. and Trickl, T.: A textbook example of long-range transport: Simultaneous observation of ozone maxima of stratospheric and North American origin in the free tropo- 
sphere over Europe, J. Geophys. Res., 104, 30445-30462, 10.1029/1999JD900803, 1999.

Stohl, A., Hittenberger, M., and Wotawa, G.: Validation of the Lagrangian particle dispersion model FLEXPART against large scale tracer experiment data, Atmos. Environ., 32(24), 42454264, 1998.

Stohl, A., Forster, C., Frank, A., Seibert, P., and Wotawa, G.: Technical note: The Lagrangian particle dispersion model FLEXPART version 6.2, Atmos. Chem. Phys., 5, 2461-2474, 2005, http://www.atmos-chem-phys.net/5/2461/2005/.

Vautard, R., Beekmann, M., Roux, J., and Gombert, D.: Validation of a hybrid forecasting system for the ozone concentrations over the Paris area, Atmos. Environ., 35(14), 2449-2461, 2001.
Vautard, R., Honoré, C., Beekmann, M., and Rouil, L.: Simulation of ozone during the August 2003 heat wave and emission control scenarios, Atmos. Environ., 39(16), 2957-2967, 2005.

Wild, O., Law, K. S., McKenna, D. S., Bandy, B. J., Penkett, S. A., and Pyle, J. A.: Photochemical trajectory modeling studies of the North Atlantic region during August 1993, J. Geophys. Res., 101, 29269-29 288, 1996.

Zhang, J. and Trivikrama Rao, S.: The Role of Vertical Mixing in the Temporal Evolution of Ground-Level Ozone Concentrations, J. Appl. Met., 38, 1674-1691, 1999. 